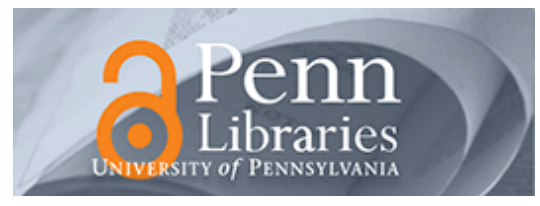

Studies in Visual Communication

Volume 9

Issue 4 Fall 1983

Article 3

1983

\title{
Clarence H. White Reconsidered: An Alternative to the Modernist Aesthetic of Straight Photography
}

Bonnie Yochelson

\section{Recommended Citation}

Yochelson, B. (1983). Clarence H. White Reconsidered: An Alternative to the Modernist Aesthetic of Straight Photography. 9 (4), 24-44. Retrieved from https://repository.upenn.edu/svc/vol9/iss4/3

This paper is posted at ScholarlyCommons. https://repository.upenn.edu/svc/vol9/iss4/3

For more information, please contact repository@pobox.upenn.edu. 
Clarence H. White Reconsidered: An Alternative to the Modernist Aesthetic of Straight Photography 


\section{Bonnie Yochelson}

Clarence H. White (1871-1925) is best known for his turn-of-the-century, soft-focus, lyrical photographs which exemplify the photographic style of pictorialism (Figure 1). White's later career as a teacher of art photography and sponsor of early commercial photography of the 1920 s is less appreciated. ${ }^{1}$ His best students-Paul Outerbridge, Anton Bruehl, and Ralph Steiner ${ }^{2}$ - developed a cubist-derived, art deco style of photography especially suited to the demands of advertising. At first glance it is difficult to see the connection between the gentle idealism of White's works and the hard-edge stylishness of the commercial works of his students. On further examination, however, an underlying artistic philosophy and view of the art-photographer can be discerned in both White and his students. One goal of this article is to elucidate the continuation of pictorialist ideas into the twentieth century.

The second, more theoretical goal is to rephrase the debate between pictorialism and straight photography, viewing the two theories as equally valid artistic alternatives. In 1902 Alfred Stieglitz founded the Photo-Secession, an organization aimed at the promotion of art, or pictorialist, photography. White, a young amateur pictorialist from Newark, Ohio, who had gained national recognition through photographic exhibitions in the late 1890s, moved to New York in 1907 to become a prominent member of the PhotoSecession group. In 1910 Stieglitz and White parted ways, and Stieglitz emerged, along with Paul Strand, in the 1920s as the elder spokesman for straight photography, a theory which favored black-and-white, high-contrast, sharp-focus, "found subject" photographs (Figures 2 and 3). By the 1930s the straight aesthetic was established as the dominant photographic mode; it laid the foundation for the documentary style of the next three decades and formed the theoretical premise for the classic histories of photography by Beaumont Newhall and Helmut Gernsheim. ${ }^{3}$ By the straight photography standard, pictorialism was old-fashioned, and White's adherence to pictorialist ideas in the wake of the new approach was considered hopelessly retardataire. ${ }^{4}$

Bonnie Yochelson is writing a Ph.D. dissertation at the Institute of Fine Arts, New York University, on the English photographer P. H. Emerson and has received an Andrew Mellon Fellowship from the Metropolitan Museum of Art, Prints and Photographs Department.
Only recently has the preeminence of straight photography been challenged. Contemporary photographers experimenting with pictorialist devices such as soft focus, manipulated negatives, and handmade papers and with commercial practices such as color, retouching, and studio setups have rejected the doctrine of straight photography. A reconsideration of White's career not only rehabilitates his reputation but sheds light on these developments. Just as White's works and those of his students provide models for commercial and pictorialist techniques, so may his ideas, firmly rooted in pictorialism, suggest a fresh historical and theoretical approach

\section{Redirecting Photo-Secession Objectives}

In the course of organizing the exhibition of pictorialist photography at the Albright Art Gallery at Buffalo in 1910, several important members of the PhotoSecession lost confidence in Stieglitz's leadership. These defectors-White, Gertrude Käsebier, Karl Struss, Alvin Langdon Coburn, and the painter Max Weber-grouped together under White's leadership to carry on the cause. Initially modeling their efforts on the Photo-Secession, the group evolved a program very different from Stieglitz's organization. White's own photographic output waned as he concerned himself more and more with the promotion of photography as a fine art. Both Stieglitz and White, from the same Photo-Secession starting point, took gradually diverging paths in the years 1910-1925. Stieglitz's path is well known. White's path, which led to the formation of three interrelated organizations - The Pictorial Photographers of America, The Clarence $\mathrm{H}$. White School of Photography, and the Art Centerdeserves more attention. ${ }^{6}$

The White group's first tasks were to find galleries other than Stieglitz's "Little Galleries" to show their work and to publish a fine-art photography journal replacing Stieglitz's Camera Work. Several exhibitions of the early teens demonstrate the group's interest in keeping alive the Photo-Secession ambition of showing not only its members' works but the best of contemporary and past photography. In October 1912 an exhibition at the Montross Galleries "illustrating the progress of the art of photography in America" updated the American section of the Buffalo exhibition; sixteen of its thirty-four exhibitors were represented at Buffalo, and it was arranged by Weber, who had hung the Albright show. Two exhibitions at the Ehrich Galleries in 1914 were grander in scope. The first, like the Albright show, was international, including works by Frederick Evans, J. Craig Annan, and Walter Bennington from England, Robert Demachy from France, and Hans Hofmeister from Germany; a young newcomer, Paul Strand, then a soft-focus pictorialist, 


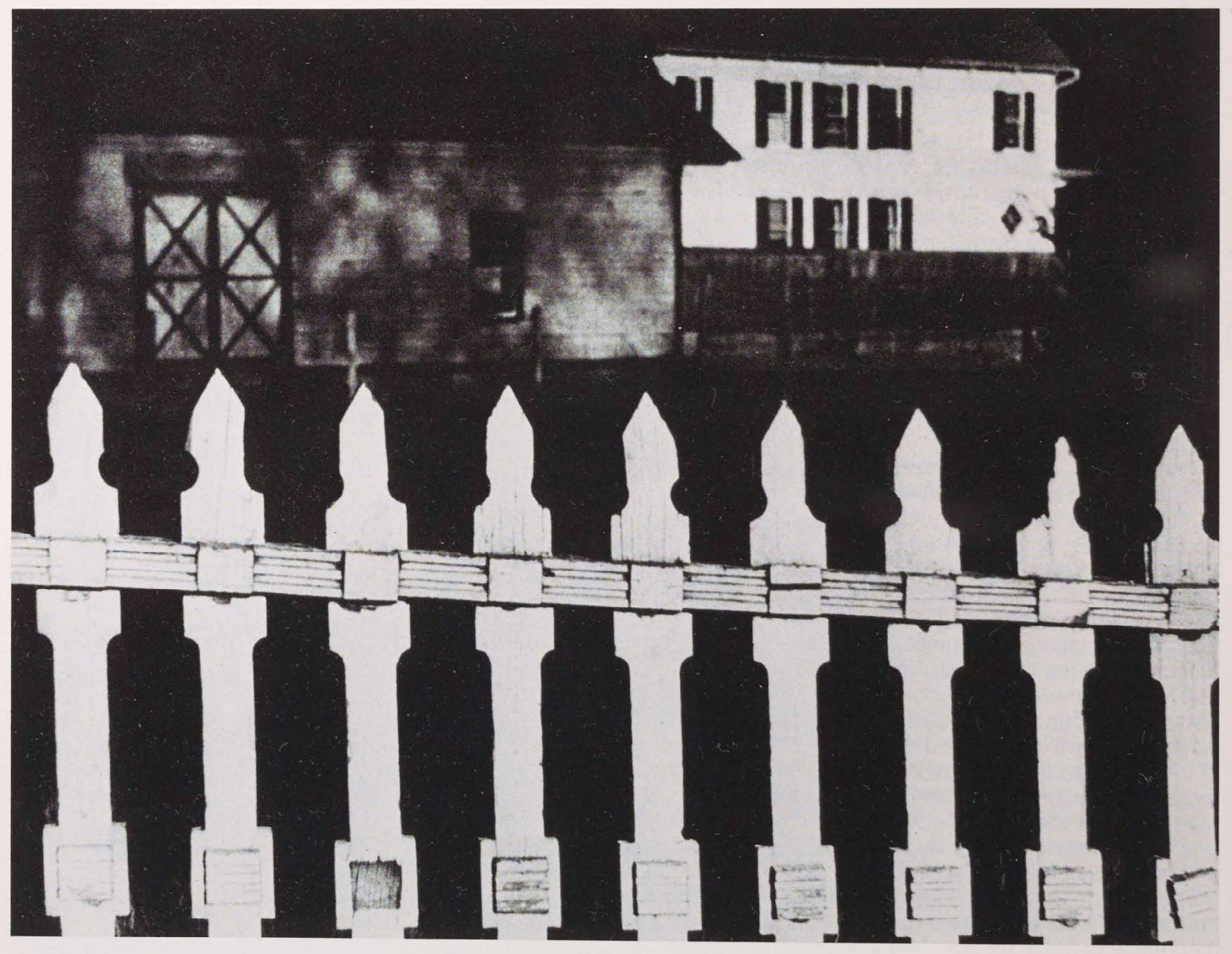


SFigure 2 Paul Strand. "The White Fence." Gravure from Camera Work, no. 49-50, June 1917. $6^{11 / 16} \times 8^{11 / 16} \mathrm{in}$. Collection, The Museum of Modern Art, New York.

Figure 3 Alfred Stieglitz. "Apples and Gable, Lake George, 1922." Silver, 115 $\times 90 \mathrm{~mm}$. National Gallery of Art,

Washington. Alfred Stieglitz Collection.

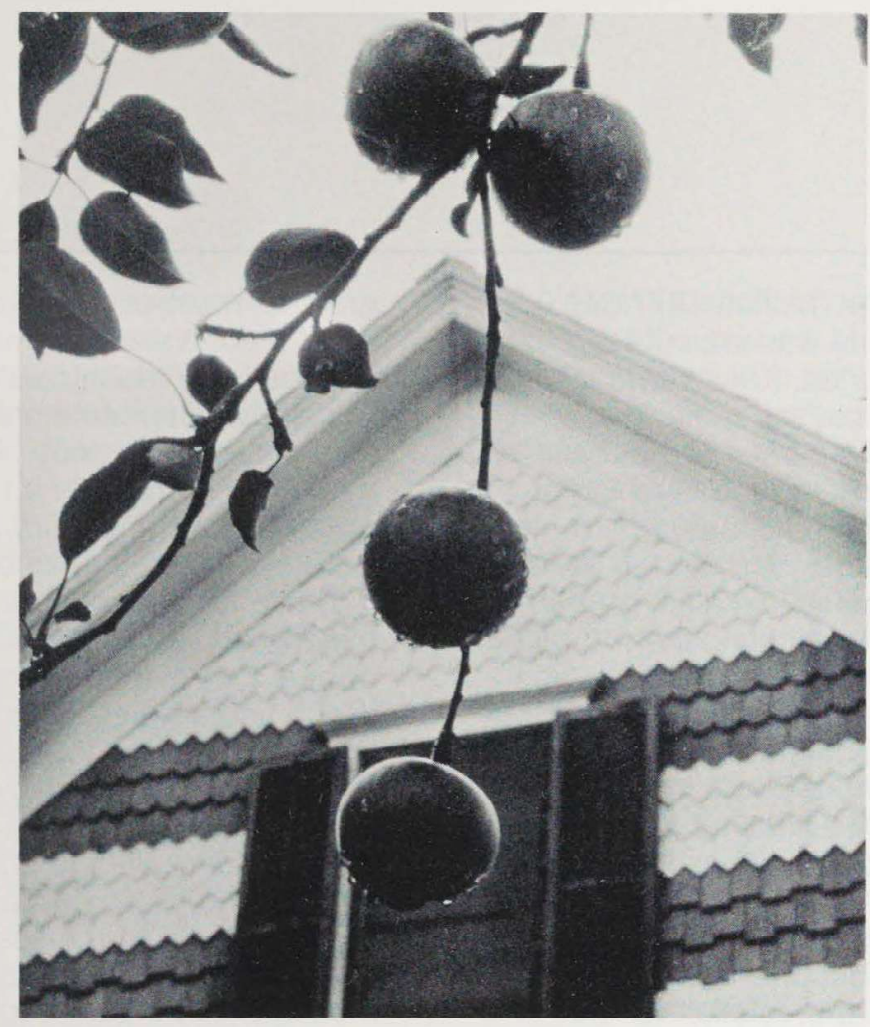

was also included. Coburn arranged the second Ehrich exhibition, which featured the two nineteenthcentury British photographers that the PhotoSecession had recognized as its precursors-D. 0 . Hill and Julia Margaret Cameron; to them Coburn added Lewis Carroll and Thomas Keith. The Albright Gallery also accepted this exhibition. In 1916 a still more ambitious historical show was arranged, tracing the progress of photography from the daguerreotype onward; it was held at the National Arts Club, where several Photo-Secession exhibitions had been held. ${ }^{7}$

In October 1913 the White Group published Platinum Print, A Journal of Personal Expression. Although not as lavish as Camera Work, it served the same purposes of providing a forum for debate of photographic issues, publishing the best art photography and publicizing photographic events. Soon renamed Photo = Graphic. Art, it ran until October 1917 , when war made amateur photographic activities difficult. Like Camera Work, the new journal published essays on modern art, especially by Max Weber, but unlike Camera Work included articles on photographic technique. It was clearly meant to fill the vacuum felt by those pictorialist photographers who lost interest in Camera Work after Stieglitz shifted its focus from art photography to modern art.

White's New York group established close contact with the Los Angeles Camera Pictorialists, founded in 1914, which was the precursor of the f64 group. As a result, the works of Imogen Cunningham appeared in the 1914 Ehrich exhibition, and in August 1914 Edward Weston's photographs were published in Platinum Print. The journal also announced the photography exhibition of the Pan-Pacific Exposition of
1915 which the Los Angeles group tried unsuccessfully to arrange. ${ }^{8}$ In 1917 the New York and California groups formed the strongest chapters of a new national organization, the Pictorial Photographers of America. White was named president and Käsebier, age 65 , was chosen a somewhat honorary vicepresident. White fared without Coburn, who had moved to England, and without Struss, who had moved to Hollywood. The PPA yearbook ${ }^{9}$ replaced Photo $=$ Graphic Art and in 1920 became the PPA annual, which appeared in 1920, 1921, 1922, 1926 (a White Memorial), and 1929. The PPA had chapters in seventeen states, and its exhibitions were nationally circulated by the American Federation of the Arts. Admitting both amateurs and professionals, it was an umbrella organization for the local camera clubs from which the Photo-Secession had originally seceded. Open membership was no doubt an effort to resolve the tensions which had arisen in 1910 when the Photo-Secession sought to sponsor the best art photography in the world and at the same time to restrict membership. In these ways, White's group built upon the Photo-Secession model, correcting what it considered the Photo-Secession's defects.

The teaching of photography was an aspect of White's program that was alien to Stieglitz, ${ }^{10}$ but one which grew out of White's Photo-Secession contacts. In 1907, the year he arrived in New York, White was appointed the first lecturer on photography as an art at Columbia Teachers College by Arthur Wesley Dow, chairman of the art department. Dow's interest in creating a course in art photography can be traced in part to his own photographic efforts; he was a prizewinning amateur art photographer and used photo- 
graphic studies for his paintings (Moffatt 1977:64 $145, n$. 198). His choice of White was undoubtedly due to his Photo-Secession friends; Käsebier taught at the Pratt Institute in Brooklyn at the same time as Dow, and Weber and Coburn had been enthusiastic Dow students. In 1908 White also began teaching at the Brooklyn Institute of Arts and Sciences, where monthly PPA exhibitions were later held, and in 1910 he began a summer school course in Maine, probably modeled on Dow's own summer school at Ipswich, Massachusetts. ${ }^{11}$

That White's circle and Dow shared the symbolist tastes for Whistler, the Nabis, and Japanese art has been noted, ${ }^{12}$ but the full extent of Dow's influence on White requires elaboration. White became a professional photographer out of economic necessity. Dow not only provided White with a teaching job but with an artistic philosophy which justified and encouraged professional photography. He became White's model as teacher, as promoter of art appreciation for the common man, and as supporter of the application of art to industrial and commercial design. His ideas were a critical factor in reorienting White away from Stieglitz.

White taught photography as a fine art by adapting Dow's book Composition. Dow set out design principles, such as opposition, or repetition, ${ }^{13}$ gave examples from the history of art, and offered exercises for the student, often asking him to make enlarged copies of the book's examples and then to draw others from nature. In much the same way, White combined specific design problems with general art appreciation in what he called the "project method," defined in a White School brochure as "a definitely graded series of technical and practical problems (which) the student is to perform under individual guidance and direction, ... supplemented and explained by lectures, demonstrations, print criticism and trips to museums."14 Specific assignments suggest Dow's technique, such as making a copy of a drawing, painting, photograph, or magazine page in half scale; or making a landscape in horizontal and vertical formats. In this way White stressed both the mastery of photographic technique and the common ground that photographers shared with all graphic artists: the selection and arrangement of perceived data into a two-dimensional pictorial structure.

White also responded to Dow's social aims for art. Dow's attack on traditional academic teaching was not intended to reform the practice of painting but to reform the elitist bias of the traditional fine arts. Inspired by the European arts and crafts movement, Dow hoped his design principles would be applied to utilitarian as well as fine art objects. To this end he drew examples from the history of textiles, furniture, and other decorative arts, and he introduced printmaking into his curriculum. In order to reach the greatest number of people, he focused on the training of art teachers-both Pratt and Columbia Teachers College were technical schools for teachers-and his Composition became universal in education schools throughout the country. To the same end, he participated in innumerable art organizations for teachers, professionals, amateurs, and craftspersons, giving lectures, arranging exhibitions, and writing articles.

These aspects of Dow's philosophy - the unity of the arts and the utility of art in daily life-held special appeal for White. By breaking down the division between fine art and decorative art, Dow encouraged White's belief that the photographer could earn his living by his art. It was Dow's inspiration, no doubt, that led to the change in title of the pictorialists' journal from Platinum Print to Photo = Graphic Art and to the introduction of a typography column in the latter journal. Dow's belief in mass education and his programmatic zeal were also exemplary for White. White's modest, midwestern origins as well as his populist socialism fostered by his early friendship with Eugene Debs made him especially open to the idea of raising the artistic awareness of the common man. White, like Dow, taught in technical, not liberal arts, schools and joined many art organizations. He was active in the American Institute of Graphic Arts, which incorporated photographs into its exhibitions, ${ }^{15}$ and in the Art Alliance, which aimed more generally at uniting art and industry. Both Dow and White addressed amateurs and professionals; their students were potential artists, art teachers, or patrons.

The third facet of White's promotion of art photography was the founding, in New York, in late 1921 of the Art Center at 65 East 56th Street. ${ }^{16}$ The center merged seven local arts and crafts organizations: the Art Alliance, the American Institute of Graphic Arts, the PPA, the Society of Illustrators (begun by Charles Dana Gibson), the Art Director's Club (led by Heyworth Campbell of Condé Nast), the New York Society of Craftsmen, and the Stowaways (a social club including members of the other clubs). The goal of the Art Center was the "fusion of beauty and utility," or the bringing together of commercial artists and potential clients. Through exhibitions, lectures, and social events the Art Center hoped to provide a showcase for modern design and to influence public taste. To this end, socially prominent sponsors such as Daniel Chester French, Louis Comfort Tiffany, Charles Scribner, Jr., and Mrs. Harry Payne Whitney helped launch the center. John D. Rockefeller, Jr., provided a three-year salary for the director, Alon Bement, a Dow disciple and photography enthusiast who taught at Columbia and contributed to PPA publications. ${ }^{17}$ The PPA held monthly exhibitions which featured older artists such as Käsebier and Arnold Genthe, students such as Laura Gilpin, Doris UImann, Paul Outerbridge, and Anton Bruehl; other New York pho- 
tographers such as Charles Sheeler and Francis Bruguière; and Californians Edward Weston and William Mortensen. ${ }^{18}$ In 1922, 1925 , and 1929 the Art Center housed the PPA-sponsored International Salon of Photography. ${ }^{19}$ White and his colleagues had clearly found a home.

\section{The Divergent Aesthetics of White and Stieglitz}

During the teens White became an increasingly public figure, and Stieglitz became increasingly private. ${ }^{20}$ Stieglitz's public appearances to photographers were sporadic: in 1913, concurrent with the Armory Show, he showed his own works at "291," and in 1916 he showed Strand's; both exhibitions were duly announced in Platinum Print. Stieglitz's 1920s exhibitions at the Anderson Galleries were received as the return of the master after a long absence. ${ }^{21}$ White, meanwhile, became a father figure for young photographers with artistic aspirations. White's style of leadership, however, could not have been more different from Stieglitz's. Stieglitz was an artistic "bolshevik" and immense ego who sought leadership of a revolutionary vanguard, first in photography with the Photo-Secession, then in painting with Steichen's guidance, and later still in photography with Strand in the late teens and twenties. He would never deign to teach photographic art, which for him was fundamentally irreducible and spiritual. And he assumed a patriarchal stance with his artists, controlling the patronage of their works. ${ }^{22}$ By contrast, White was an artistic "democrat" who lacked both Stieglitz's charisma and ego. His approach was self-effacing, flexible, permissive, and practical. Like Stieglitz, he held firmly to a belief in the spiritual core of art, but unlike Stieglitz, he tried to isolate the teachable aspect of photographic art. He was an endless source of encouragement and support ${ }^{23}$ and helped his best students by finding them jobs; he appointed Outerbridge and Bruehl teachers at his school, and he arranged Ralph Steiner's first job working for the photogravure company which had produced Camera Work.

Although rooted in the same Photo-Secession source, Stieglitz's and White's aesthetic beliefs - their understanding of pictorialism, straight photography, and modern art-grew increasingly incompatible. For the Photo-Secession, pictorialism did not mean a particular style but rather the practice of photography as a fine art and as a means of personal expression. Such was the meaning of pictorialism used by Stieglitz in the title of the Buffalo exhibition, ${ }^{24}$ and the meaning that White continued to accept when the PPA was named. Straight photography was simply one aesthetic and technical option available to the pictorialist: the printing of an unmanipulated negative on platinum paper. In debates that persisted in the photographic journals of the 1890s, a straight print was contrasted with gum bichromate or oil processes which permitted handwork on the negative in the darkroom. A straight platinum print, by Frederick Evans or Stieglitz, was a gray image whose delicate tonal range and minute detail could be recorded only by the camera. A gum or oil print, by Robert Demachy or Edward Steichen, could be colored, could produce a very generalized effect, and because of the handwork could be mistaken for a drawing or a pastel. ${ }^{25}$

In the mid-teens Stieglitz and his protégé Paul Strand began to evolve a new concept of straight photography to explain the dramatic originality of Strand's 1915-1916 photographs, which were shown at "291" and published in Camera Work, and of Stieglitz's works, which were shown at the Anderson Galleries in 1921, 1923, and 1924. By the 1930s, when Stieglitz and Strand became more familiar with the 644 photographers, the new position coalesced. To the older idea of the unmanipulated print was added a new approach to subject matter: direct, uncompromising, and confrontational. The untouched negative was no longer a preference but a prerequisite; and darkroom manipulation was seen as an obstruction to the photographer's primary experience of finding a subject. Although Strand and Stieglitz eschewed definitions of style, a preference for higher contrast and sharper focus enhanced the confrontational effect. Pictorialism, according to this view, was a repository of old-fashioned ideas. Its preferences for soft focus and a narrow tonal range ${ }^{26}$ and its preoccupation with elaborate craftsmanship were rejected. Most damnable was the pictorialist effort to unite photography with other arts in appearance and in principle. The older idea that a straight photograph looks only like a photograph, not like a painting or drawing, became the central tenet of the new straight photography. The pictorialist's flexibility on this point, particularly in Strand's view, was fatal. ${ }^{27}$

White remained loyal to the older view that straight photography was one option available to the pictorialist photographer. In fact, he and his circle favored straight photography - the unmanipulated negative printed on platinum paper-from the start. The title of their first journal, Platinum Print, indicates this preference, as does a review in Platinum Print of their 1914 Ehrich Galleries exhibition that called the show "pure and clean .... indicating a high attainment of what is known as straight photography" (Platinum Print, March 1914:6). ${ }^{28}$ However, White never rejected alternative styles. In an interview published in the 1921 PPA annual White made clear his continued adherence to the older view. Asked about handworked versus straight prints, he replied 
I do not have any objection to anybody using any method that he pleases providing that the result is convincing on the other hand, some of the best and probably more good pictures have been produced by not using them, that is by making the pictures straight. [Moore 1921:6-10]

In the face of the restrictive, supposedly purifying, force of the newly defined straight photography, White retained his belief in the primacy of artistic result by any photographic means.

Stieglitz and White also approached the problems posed by modern European art to American photography in very different ways. Although the modern artists shown at "291" and at the Armory Show are frequently cited as an influence on Strand's and Stieglitz's later work, ${ }^{29}$ both photographers minimized this connection. Their campaign for straight photography stressed subject matter over formal considerations and the independence of photographic aesthetics from other arts. Their effort to define photography's uniqueness, however, was itself an expression of modernist aesthetics of the late teens and twenties. Straight photography, like Suprematist painting or International Style architecture, was an acsthetic system which stated the presumably timeless, fundamental principles of a medium and avoided defining the characteristics of a mere historical style. Consequently, the stylistic innovations of straight photography were not explicitly defined. The abstracting and flattening of form which results from extremely high or low viewpoints, close-ups, and odd cropping, and the relation of these devices to cubism, purism, and constructivism, have only now begun to be explored. Instead, the rhetoric of straight photography was metaphysical-concerning the unique powers of the camera to penetrate reality - and moral-concerning the photographer's purity of expression and honest use of his remarkable tool. ${ }^{30}$ To discuss the structure of photographs in terms equally applicable to other two-dimensional images denied photography's unique properties and was therefore taboo.

White, unlike Stieglitz, enthusiastically acknowledged that modern painting offered valuable lessons to photography. For just that reason he hired painters to teach the art appreciation or composition classes at his School of Photography. The first art teacher was Max Weber, who was followed in 1918 by Charles Martin, a Dow disciple who was more open to modernism that Dow himself (Moffatt 1977: 122 and n. 286). Weber, whose aesthetics blended French cubism with Kandinsky, ${ }^{31}$ stressed the concept of "space-filling," a natural outgrowth of Dow's design principles. Dow had tried to shift the artist's attention from traditional imitation of nature (for the photographer, recording of nature) to the expressive possibilities and intellectual challenges of pictorial construction. Weber's goal was the same, but his pic-
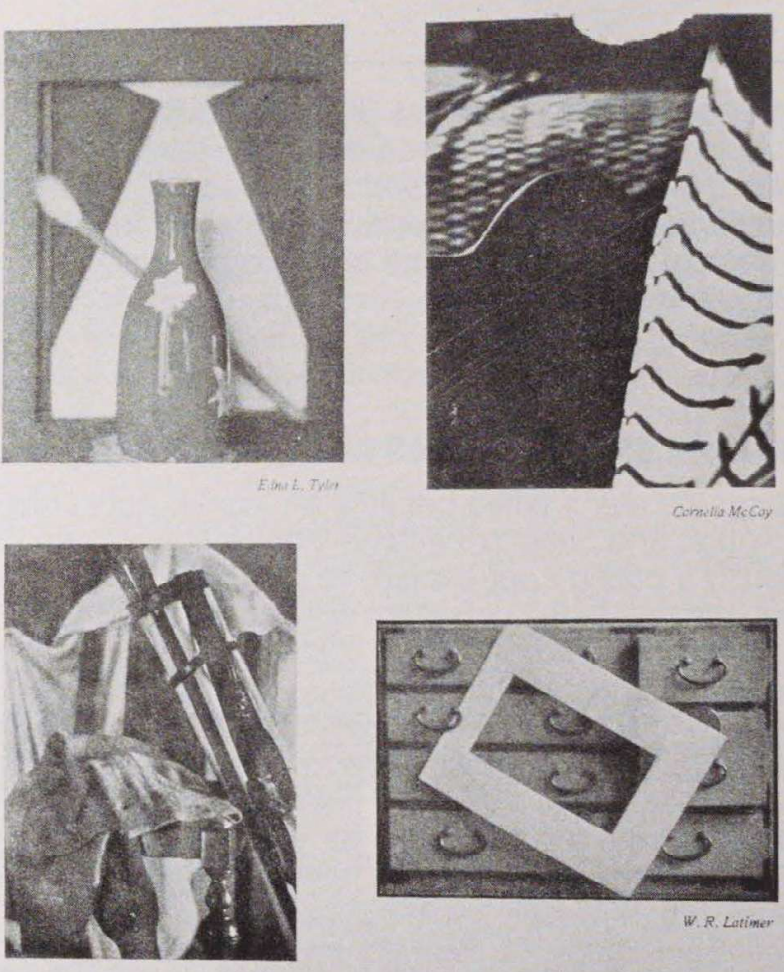

WV. R. Latimer

DESIGN

Figure 4 "Design," exercises by students of Max Weber at the Clarence H. White School of Photography. In Photo $=$ Graphic Art 3(1), June 1916. Courtesy of the New York Public Library.

torial models were more adventuresome in their departures from nature. His 1913 Platinum Print essay, "The Filling of Space," conveyed his modernist message to the photographer

The page of the canvas is empty, but pregnant with birth as in space, waiting for the touch of the inspired mind

In our choice and elimination lies the very character of our personality, the very quality of our taste and expression. [Weber 1913] [ $^{32}$

His emphasis on selection gave space-filling a specifically photographic character. ${ }^{33}$

White's idea that a painter could stimulate a new photographic style by teaching modern art to beginners did not succeed. Weber's students' design exercises were published in the June 1916 issue of Photo = Graphic Art, with the aim of bringing "as much of the abstract into (one's) expression as the photograph will allow." 34 The students tried to translate the spatial ambiguities of cubist painting into actual still life but then photographed the arrangements in an entirely conventional way (Figure 4). Although Coburn, in his often-cited "The Future of Pictorial Photography" (Bunnell 1980:194-195), commended 
these "groups of various objects photographed because of their shape and colour value, and with no thought of their sentimental associations," the works fail as photographic abstractions, especially in comparison to Strand's and Coburn's abstract works of the teens. ${ }^{35}$ The photographs lack precisely the kind of selection - of viewpoint, lighting, and croppingthat Weber had hoped for in his call for space-filling

Despite its failure in design class, space-filling played a vital role in White's own later photographs In a series of photographs of shipbuilding done in Bath, Maine, in 1917, White created near-abstract compositions, while at the same time retaining the pictorialist preference for soft focus and the narrow tonal range of platinum printing (Figure 5). ${ }^{36}$ Thus he mixed older pictorialist devices with the new compositional experiments. Indeed, when asked in 1921 what the key changes had been in the last twenty years of photography, White mentioned both the soft-focus lens, which was invented by his close friend Karl Struss, and the better sense of picture construction, which no doubt for him was due to Weber's influence (Moore 1921:6-10).

White's eclecticism has been harshly judged. By the standard of straight photography, his reluctance to espouse sharp focus and his overt reliance on concepts borrowed from painting indicate a failure of nerve and an unwillingness to depict clearly his subject and to free himself from the artificiality of preconceived design principles (Pultz and Scallen 1981:11). ${ }^{37}$ This view, however, fails to account for White's own values. He considered the photographer's choice of focus, composition, subject, and method of printing as variables subject to free combination. Although he personally preferred platinum printing and the soft-focus lens, he remained open to any photographic experiment. His undogmatic, heterogeneous approach is reflected in the project assignments at his school. One required three sepia-toned platinum prints; another a photomontage, photogram, or multiple exposure. Others, although designed for technical difficulty, reveal varying aesthetic biases: a photograph of a glass of milk and glass of water on an all-white background recalls the high-key subtleties of pictorialism; three photos of cloth or fur demand a sharp-focus rendering of texture or geometrical patterning (White School brochure). These exercises show White's commitment both to technical versatility and to the ever-expanding potentialities of photographic art. In this way he carried the devices and principles of pictorialism into the 1920 s.

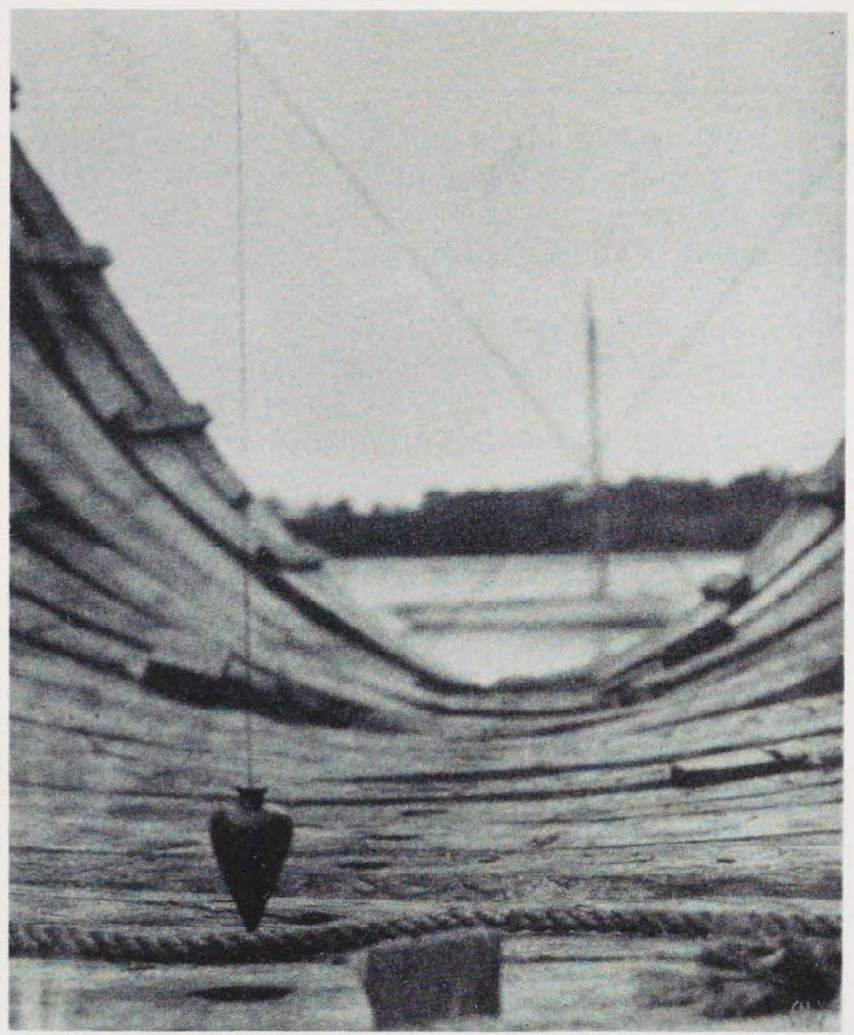

Figure 5 Clarence $\mathrm{H}$. White. "Ship Construction, Bath, Maine," 1917. Platinum print, $4 \frac{1}{2} \times 3 \frac{1}{16}$ in. Collection, The Museum of Modern Art, New York. Gift of Mr. and Mrs. Clarence White, Jr.

\section{White and the Emergence of Advertising Photography}

White's belief in the commercial application of photographic art was anathema to Stieglitz and was in fact an important reason for their 1910 estrangement (Naef 1978:182). The legendary stories of Stieglitz's refusal to sell works to "unsuitable" buyers shows his vehement effort to separate art from commerce (e.g., Homer 1977:80). White, by contrast, conscientiously worked to fuse art and commerce, which was the very purpose of the Art Center. The practice of commercial photography in 1910, however, was very different from its practice by the end of White's life in 1925. In 1910 artistic commercial photography meant either the portraiture of Baron de Meyer, Käsebier, and Arnold Genthe or fine art illustration, such as Genthe's Old Chinatown (1913) and Coburn's Men of Mark (1913), which combined both portraiture and illustration. By the late twenties, photography dominated magazine illustration and advertising; Condé Nast's publications, Vanity Fair and Vogue, led the field, ${ }^{38}$ with White a key figure in this development. 
In 1920-1921 a series of full-page "artistic" photographs appeared in Vanity Fair, ${ }^{39}$ the cultural mouthpiece of Condé Nast. It is very likely that White, whose own "On the Sand Dunes" was printed in Vanity Fair in 1915, prompted this series. Since the Photo-Secession days, ${ }^{40}$ White had been a close friend of Heyworth Campbell, the art director of Condé Nast from 1910 to 1923, who was also a principal figure at the Art Center. In its December 1920 and January 1921 issues, Vanity Fair published a pair of pictorialist, "arcadian" dance photographs by Californians, the first by Struss and the second jointly by Edward Weston and Margarethe Mather. ${ }^{41}$ In 1921, it featured several experimental modernist photographs, including "cubistic architecture" by Charles Sheeler, photograms by Man Ray, and light abstractions by Francis Bruguière. Also appearing in 1921 were the works of two White students who by their obscurity support the idea that White was behind this series. The July issue included "Experiments in Modern Photography" by Ira Martin, a PPA officer who became the photographer for the Frick Collection. His light abstractions using cut paper and multiple light sources were derived from Bruguière's, which had been published three months earlier. In the October issue Margaret Watkins, another White protégé who later became a portrait and advertising photographer, was featured with "Photography Comes into the Kitchen," a series of still lifes most likely derived from White school design exercises. Her "Domestic Symphony" (Figure 6), which also appeared in the 1922 PPA annual, used everyday objects to create an elegant, curvilinear composition. Its velvety black void at the center is a bold step away from the concern with subject matter, and its musical title recalls Weber's symbolist-derived concept of formal and expressive correspondences.

All these photographers also appeared soon thereafter in Vogue. Their assignments, which featured either architectural and interior designs, theater set designs, or accessory display, took them out of the realm of pure art photography. Some of the results were artless, such as Man Ray's architectural photographs from Paris [e.g., Vogue (April 1, 1928, p. 86)], but some were indistinguishable from works of art, such as Sheeler's architectural assignments, which sometimes became studies for architectural paintings. ${ }^{42}$ These same artists, with the exception of Man Ray, were given one-man shows at the Art Center. White thereby helped photographers show their work and sell it, whether they were his students or independent artists pursuing similar goals.

At the same time that art photographs were beginning to appear in print, the expanded possibilities of photographic product advertising were becoming apparent. The first Art Center exhibition catalog made the connection

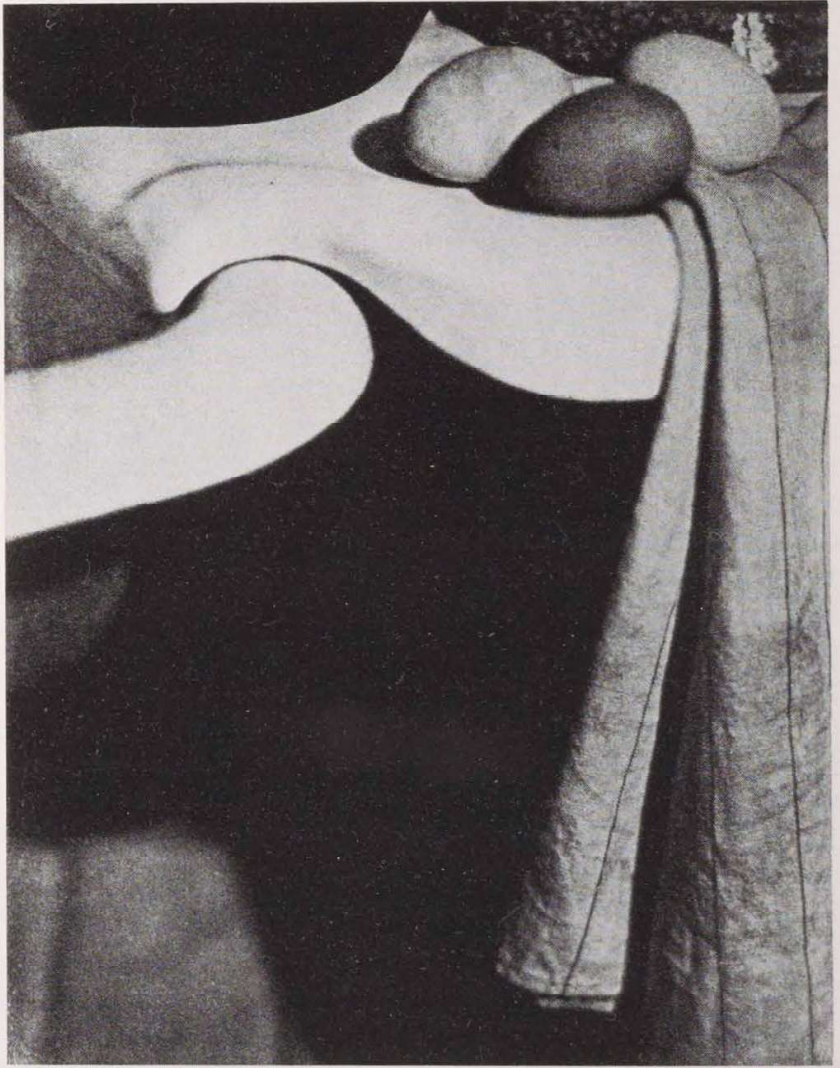

Figure 6 Margaret Watkins. "Domestic Symphony." In Pictorial Photography in America 3, 1922, plate 77. Courtesy of the New York Public Library. 
The visitors will be interested in the recent developments in artistic photography as applied to modern advertising shown in these galleries. It is not impossible to make a beautiful composition of objects which are illustrations in an advertising page of our popular magazines, or in other printed matter, and the American advertiser is becoming more and more aware of this fact. [Art Center 1921]

In November 1919 the journal Photo-Miniature devoted an issue to "Marketing Photographs for Advertisers" [15(177):365]. The publisher of PhotoMiniature and author of this issue was John Tennant, an old friend of White and publisher of the PPA annuals. He wrote optimistically of a new consumeroriented world and the "fight to the finish between the camera and the pen, pencil and brush":

The time is ripe for such an awakening on the part of photographers. Ours is a pictorial age. The end of the world war has opened a thousand new fields to manufacturers and advertisers the world over. The $(y)$... are keenly alive to the value of illustration in advertising, and spend unstintingly for pictorial material.

Tennant's analysis is remarkably prescient, for he wrote about modern advertising style before it had begun to appear with any regularity. He distinguished the two older styles - the soft-focus "artistic effect" used for illustration and the "mechanically accurate" style-from the "more modern, more subtle straight style." The modern style was preferred for its ability to "awaken a keen sense of possession" in the viewer. Tennant suggested that the airbrush be abandoned in favor of "modern retouching": straight printing and reflected lighting. When composed with design or pattern making in mind, such works would render textural surface and create what Tennant called a "happy arrangement." Using "straight" in the old, technical sense, he realized that the new style, which was compatible with the design exercises of White's School, involved as much manipulation as pictorialism; the locus of manipulation had simply shifted from the darkroom to the studio arrangement of the subject.

The disadvantages of the two older styles are seen in a 1921 Ivory Pyralin ad in Vanity Fair (Figure 7). The soft-lit girl with flowers depicts "the youthful charm of graduation day"; she lends human interest but provides no product information. The comb and brush set at lower right, photographed in a heavily airbrushed and pedestrian manner, is the recommended graduation gift. The viewer must take time to read the caption and associate the product with the narrative. Further hindering the effectiveness of the advertisement is the unavoidably poor quality of the tonal, pictorialist photograph in reproduction.

By contrast, Paul Outerbridge's well-known "Ide Shirt Collar" 43 in a 1922 Vanity Fair illustrates the ad-

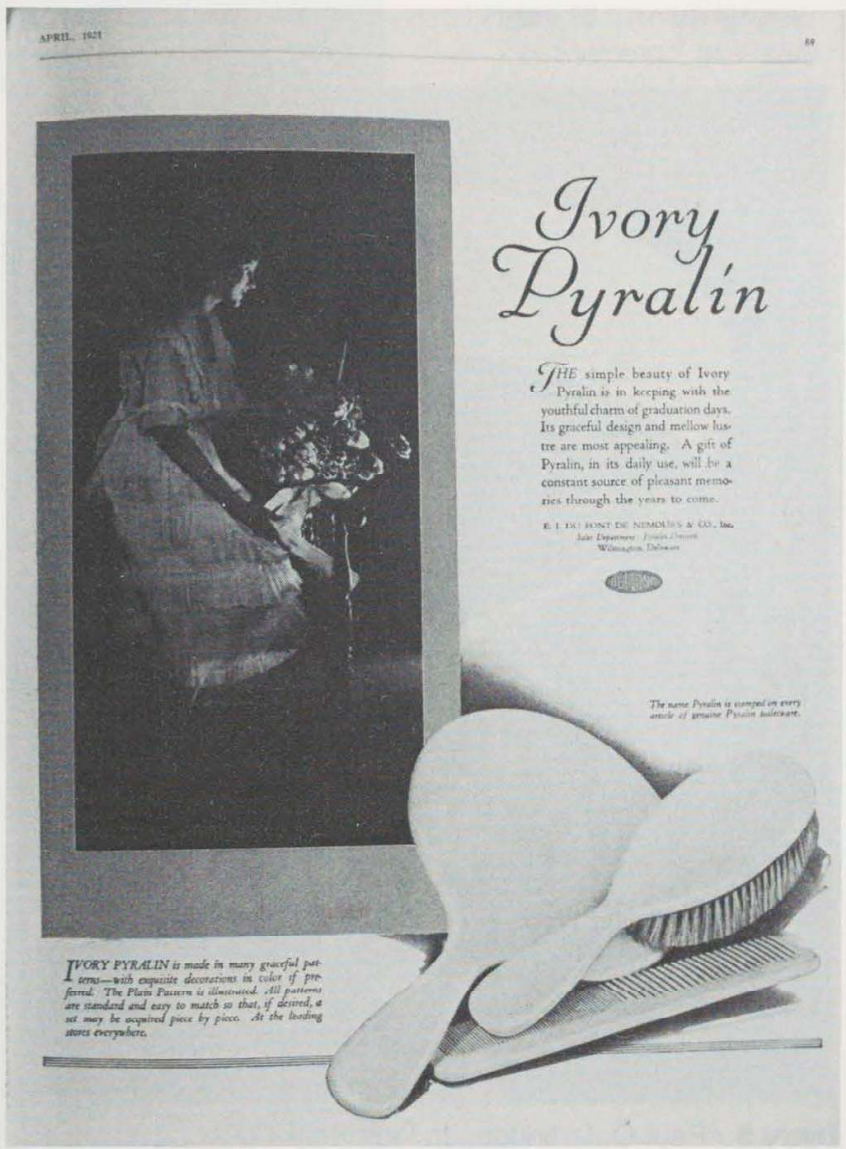

Figure 7 "Ivory Pyralin Advertisement." In Vanity Fair (April 1921), p. 89. Courtesy of the New York Public Library. 


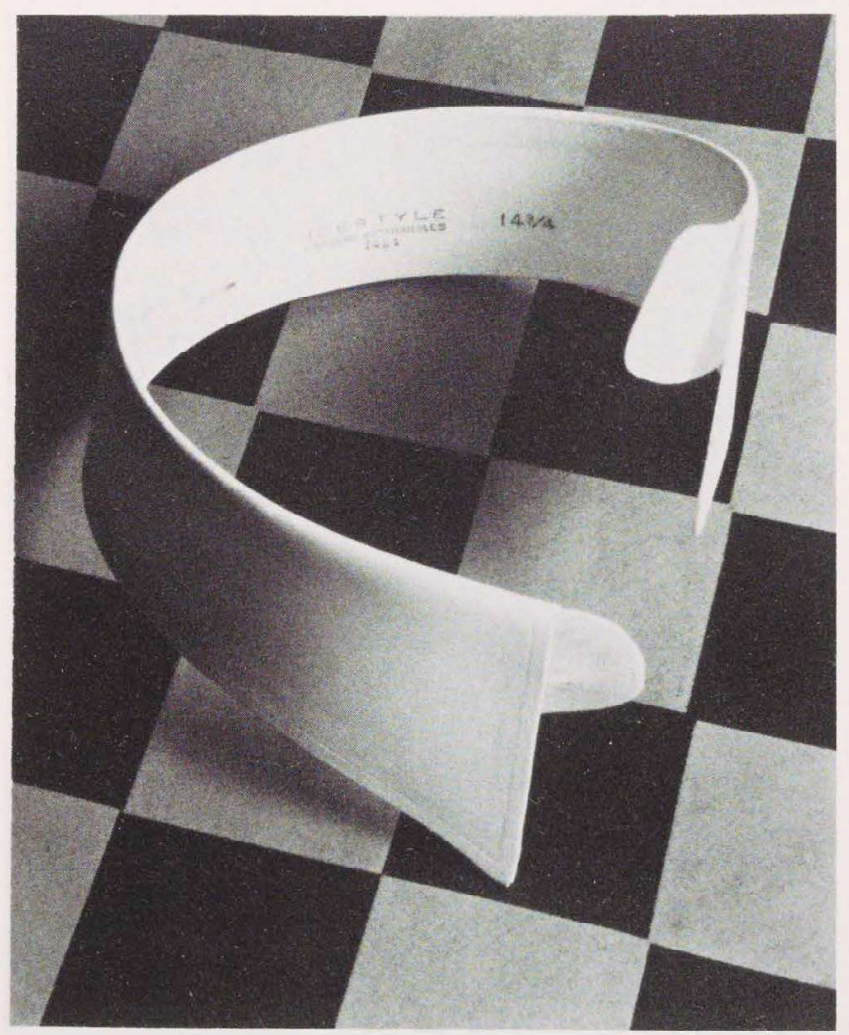

Figure 8 Paul Outerbridge, Jr. "Ide Shirt Collar," 1922. Gelatin-silver print, $4 \frac{1}{2} \times 3 \frac{5}{8}$ in. Collection, The Museum of Modern Art, New York. Gift of the photographer.

vantages of the newer style (Figure 8). The sculptural white collar seems suspended against the flat, diamond-patterned floor, which is shot from an overhead, oblique angle. The elegant curve and subtle modeling of the collar suggest the elegance of the wearer. The sharp focus permits the legibility of the trade name inside the collar as well as the neck size, $143 / 4$, of the slim imaginary owner. In an instant the necessary information and the temptation to buy are conveyed.

In the course of the twenties, these commercially viable still-life experiments became increasingly elab orate through experimentation with artificial light; reflections, mirrors, and the transparency of objects came to be exploited. For example, Outerbridge, in his powder box of 1925 (Figure 9), placed the box in a paper construction lit to repeat or rearrange parts of the shape of the box itself; the box seems suspended in an environment which only it could inhabit. In 1929 Ralph Steiner and Anton Bruehl began collaborating on Vogue's Christmas gift layouts. They created visual conundrums that attempt to confuse spatial recession

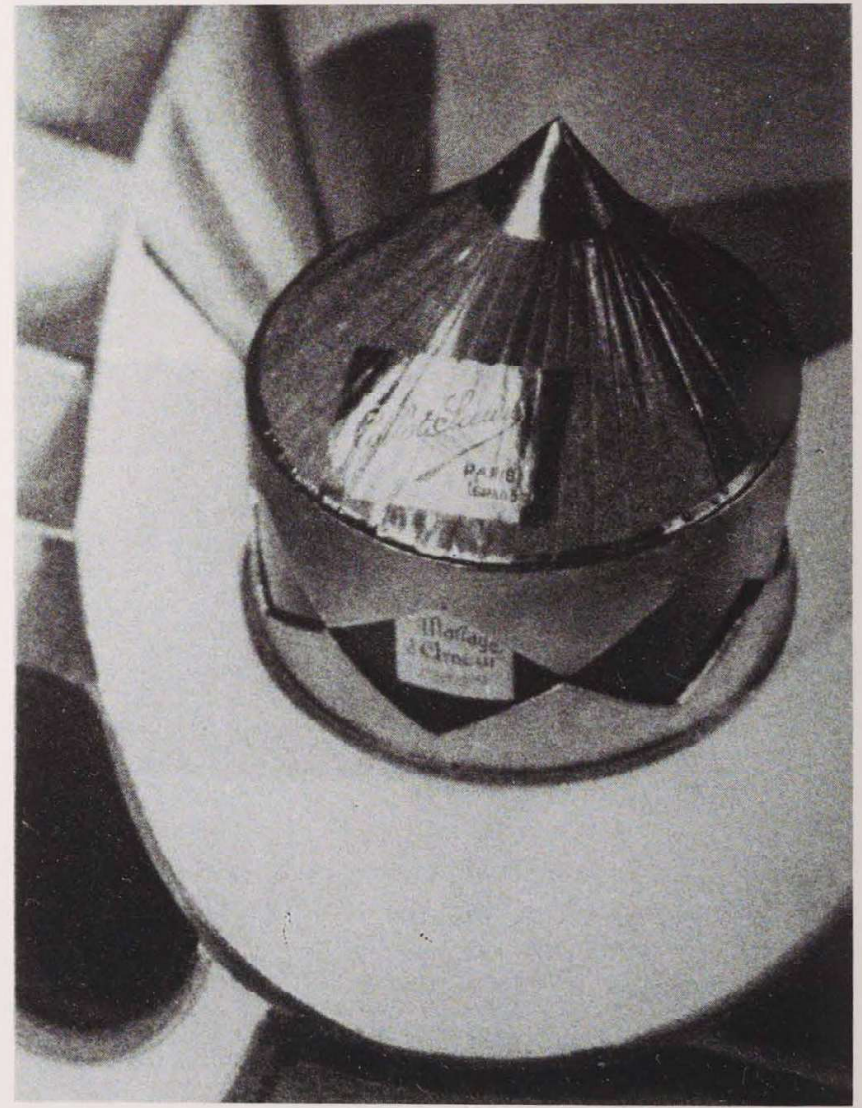

Figure 9 Paul Outerbridge, Jr. "The Perfume of the Couture." In Vogue 66 (November 15, 1925), p. 66. Courtesy of the New York Public Library.

and the flatness of the picture plane. In "For Evening" (Figure 10), for example, Bruehl made a construction which appears vertical on the surface and, at the same time, receding into the background; he deliberately masked junctures within the setup with the objects on display to enhance the spatial ambiguity. While these experiments derive from cubist ideas about space and form, the results are not intended to fragment form or to disrupt reality, but rather to catch the eye and demand a second or third look.

White's contacts and his teaching were crucial factors in the development of commercial photography, and his students were among its pioneers. However, two independent factors were essential to its enthusiastic acceptance and burgeoning growth. The first was the return of Edward Steichen from France and his appointment as chief photographer at Condé Nast in 1923. Steichen, enormously respected for his Photo-Secession work and his connections with the French art world, had virtually disappeared after the war; his reappearance as a proponent of modernism and commercial photography had an immediate and 


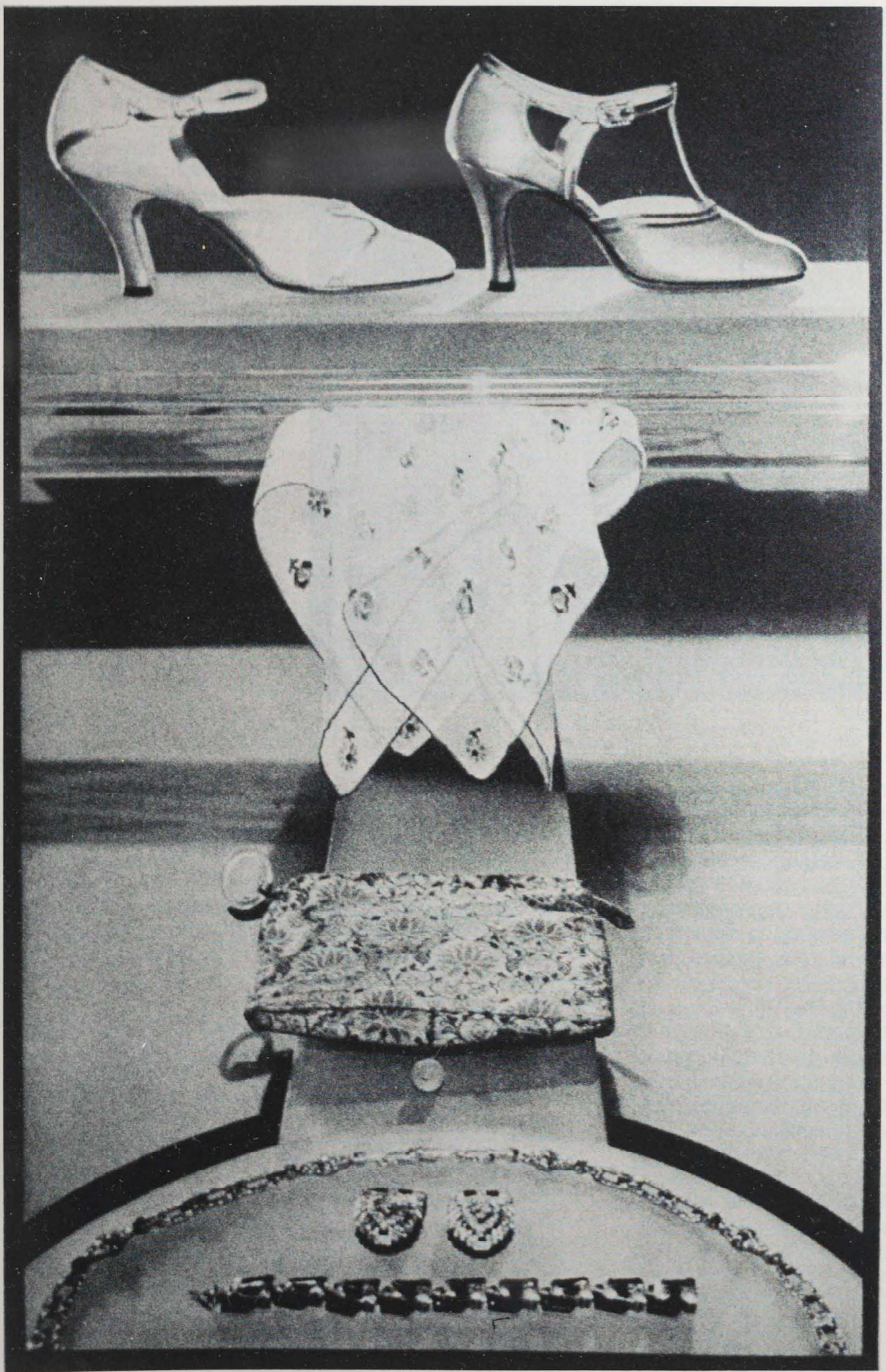

Figure 10 Anton Bruehl. "For Evening." In Vogue (May 11, 1929), p. 92 Courtesy of the New York Public Library. 


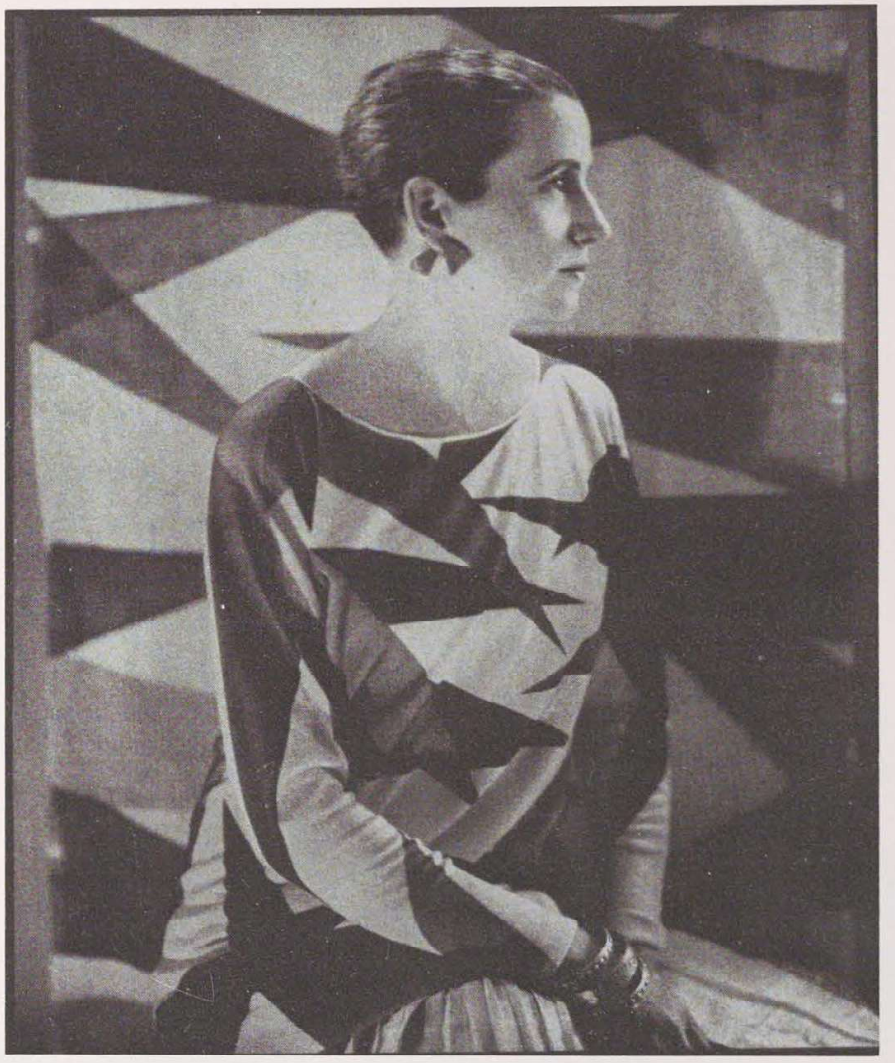

Figure 11 Edward Steichen. "Madame Agnès, Who First Sponsored Modernism in Dress." In Vogue 66 (October 1, 1925), p. 71. Courtesy of the New York Public Library.

powerful impact. In 1923 Stcichon spoke to the PPA at the Art Center. ${ }^{44} \mathrm{He}$ was asked to what school of photography he now paid tribute and replied, "The worldwide movement in literature, science and all the arts." As to whether photography was an art, he answered, "Why worry? Let it be a good photographthat is enough." His glamor and success as well as his fresh ideas were not lost on the PPA audience.

Steichen's influence also undoubtedly explains Heyworth Campbell's about-face on the subjects of modernism and commercial photography, a change dramatically illustratcd by a comparison of two statements he made to the PPA. ${ }^{45}$ In 1922 Campbell violently rejected modernist photographs, finding them symptomatic of a universal cultural malaise:

The weird conceptions and grotesque ideas in back of most of the unsolicited material submitted would make one easily believe that the artists are inmates, or perfectly qualified to be inmates of asylums. ... Owing to the restlessness of the world situation - wars and rumors of wars, strikes and overtendency toward jazz and slang - there is already, especially in the work of youngsters, too evident an urge to be different, different merely for the sake of being different.

By 1924 he had totally reversed his position. The new style was no longer symbolic of rebellion but a formal means that could serve varied ends, including those of advertisers:
Art is not a thing to be done, but the best way of doing that which is necessary to be done. This brings a tobacco advertisement into the realm of art as truly as the designing of a cathedral.

Campbell claimed that "to attract attention a picture should be dramatic, even sensational, modern, spectacular," and he demonstrated his point with a Steichen photograph of a lily.

The second factor assuring the success of the new commercial photographic style was art deco, which conquered the world of fashion in the late twenties. Vogue, an arbiter and monitor of American taste, reflected American Francophile sentiments in the years following World War I. It advocated nineteenth-century French decoration and less enthusiastically reported on postcubist French painting. A 1920 review of the Salon d'Automne claimed that the novelty of modernism had worn off: "Nowadays a shrug is sufficient comment for the most modern of canvasses" (Vogue, February 1, 1920, p. 128). This sophisticated apathy toward French modernism persisted until the 1925 Paris Exposition des Arts Décoratifs, which initiated art deco and hit America "like a tidal wave" (Vogue, June 1, 1928, p. 80). Art deco presented a modern, cubist-derived style entirely consistent with the ornate elegance and fine craftsmanship of traditional French design. ${ }^{46}$ Within a few years art deco styling dominated clothing, furnishings, and the graphics of Vogue. A 1928 series of articles on twentieth-century decoration proclaimed that "shop windows, dress- 
Figure 12 Edward Steichen. "A Short Cape Takes a Circular Way Southward." In Vogue 67 (January 1, 1926), p. 77. Courtesy of the New York Public Library.

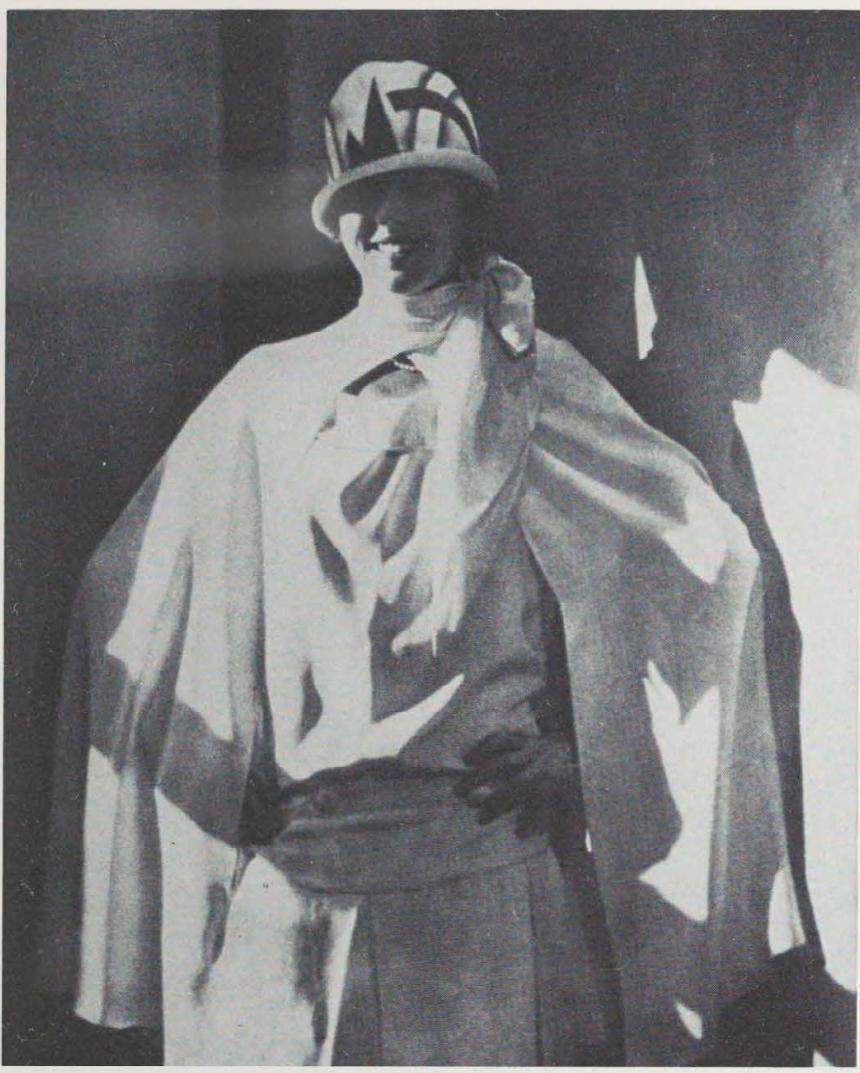

making establishments and advertising [had] all gone modern (Vogue, June 1, 1928, p. 80). The mania for modern French design soon led to an interest in Scandinavian and the more rigorous forms of German design (King 1929). Similarly, in 1926 and 1927 the Metropolitan Museum, which likewise had rejected modern painting, held exhibitions of French and then American industrial design, and the Art Center soon followed suit (Richards 1926; Reed 1929).

Art deco contributed to commercial photography's assimilation of modernist stylizations. Outerbridge had created cubist-influenced still lifes used for product advertising before 1925. Steichen, however, did not "go modern" until art deco arrived. He started at Condé Nast in a more old-fashioned style based on Baron de Meyer. Then in 1925 he took his first tentative steps toward geometrical patterning. His 1925 "Portrait of Madame Agnès" (Figure 11) "who first brought modernism to dress" shows that he had yet to learn the secrets of artificial light; as he confessed in his autobiography, before coming to Condé Nast he had never used artificial light, but gradually "there were lights all over the place" (Steichen 1963). His setting Mme. Agnès against a patterned backdrop and photographing her conventionally recalls the failed Weber design experiment of 1916 in which a "cubistic" construction was photographed without regard to cropping or lighting. By 1926, however, he had begun to experiment with light, pattern, and re flection, quickly becoming the most influential practitioner of the new style. In "The Short Cape" (Figure
12) a complex pattern of light and shadow functions independently of figure and clothes, a device repeated in the decoration of the model's hat. In the 1927 "Shoes" (Figure 13) the objects are splintered and multiplied by spotlights and mirrors

Art deco also influenced the style of Bruehl's and Steiner's product displays of the late twenties. Their compositional experiments derive from White design exercises, but their use of higher contrast, sharper focus, and more elaborate geometrical patterning is due to art deco. The inherent geometry of deco objects contributed to the style, as Bruehl's 1929 "Modern Teasets" (Figure 14) demonstrates. The forms seem flattened, tipped-up against the picture plane, and the reflective surfaces add to the patterning of the surface and distort the wholeness of individual objects.

White, who died in 1925, did not see the success of the art deco style of advertising photography that he had fostered. The addition of an advertising section to the 1926 White Memorial PPA annual, which featured works by Outerbridge, Bruehl, Steiner, and Margaret Watkins, was a fitting tribute to his pioneering role. In her introduction to the section Watkins encapsulated the evolution of commercial photography from the point of view of White's students. PhotoSecession gentility and art for art's sake philosophy, she observed, had been disrupted by the influence of modern painting on photography; modern painting offered a new formal approach to art which the photographer could adapt and the advertiser could exploit: 
Figure 13 Edward Steichen. "Shoes." In Vogue 69 (June 15, 1927), p. 60. Courtesy of the New York Public Library.

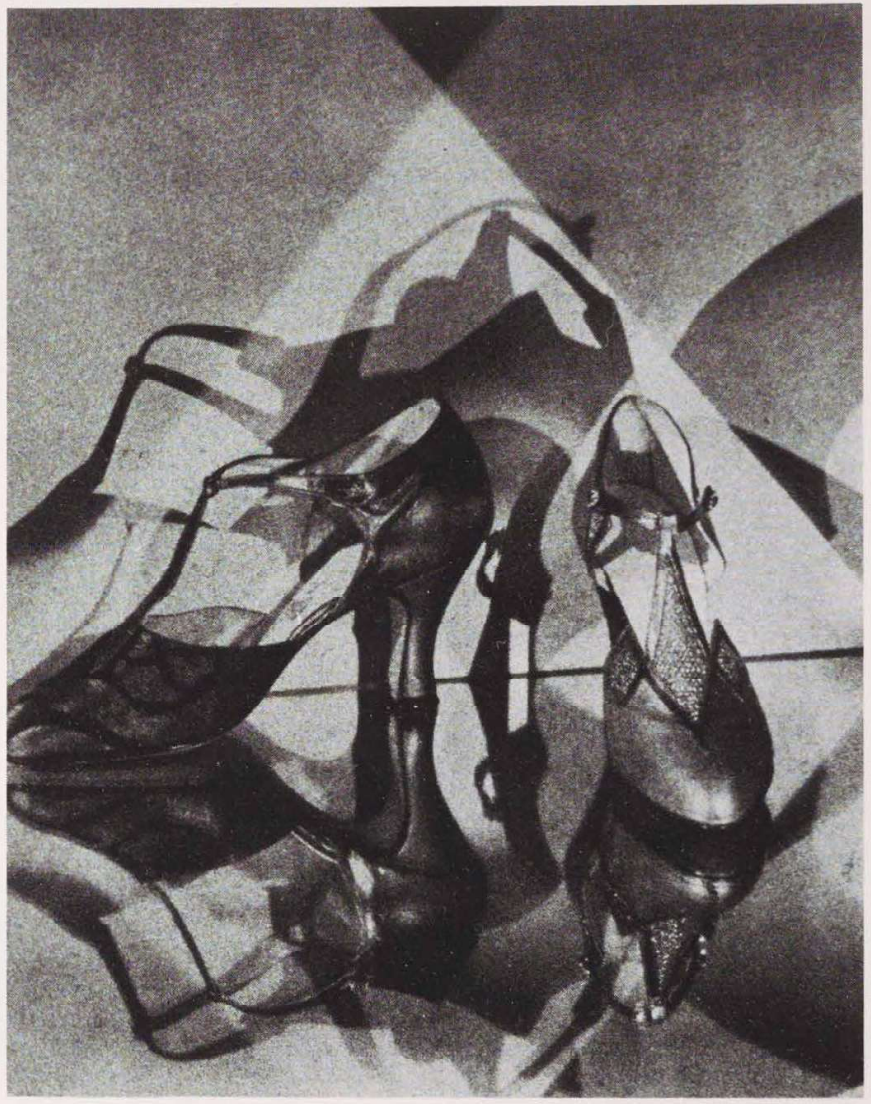

In the days of the Photo-Secession the artistic and commercial photographers were mutually unaware. No devout pictorialist would have deigned to descend to advertising. In their desire to establish photography as an art they became a bit precious; crudeness was distressing, materialism shunned.

With Cézanne, Matisse, Picasso, came a new approach. Soulfulness was taboo, romance derided, anecdote scorned; beauty of subject was superseded by beauty of design, and the relation of ideas gave place to the relation of forms. Weird and surprising things were put upon canvas; stark mechanical objects revealed an unguessed dignity; commonplace articles showed curves and angles which could be repeated with the varying pattern of a fugue. The comprehending photographer saw, paused, and seized his camera! And while the more conservative workers still exhibited photographs beautiful in the accepted sense, strange offerings startled the juries. . . But the eye of the advertiser was alert. Here were possibilities. ${ }^{48}$

\section{Assessing White's Perspective}

There are various ways to assess the artistic viability of the new commercial photography. Stieglitz and Strand totally rejected both the elegant artifice of the style and the compromise of art to a client's demands. When invited by White in 1923 to speak at the Art Center and the White School, both advocates of straight photography rudely denounced the beliefs of their host and audience. ${ }^{49} \mathrm{~A}$ related reaction was that of Ralph Steiner, who began as a White protégé but espoused straight photography after befriending Strand in 1928. Steiner became a critic of his White training, declaiming the stress placed on art principles and separating his ambitions as an artist from his commercial assignments. Unlike Strand, who believed on principle that commercial photography could not be art, Steiner's choice appears more personal, for he recognized that commercial photographic art was possible. His opinion of Steichen, the consummate commercial success, is remarkably fairminded:

Many young photographers brought their work to Steichen and asked him how to use their camera for earning a living. Steichen would tell them to wrap packages at Macy's in order to eat, and to photograph in their spare time. He may have realized that what worked for him and made him happy might destroy the talent of others. [Steiner 1978:16] 


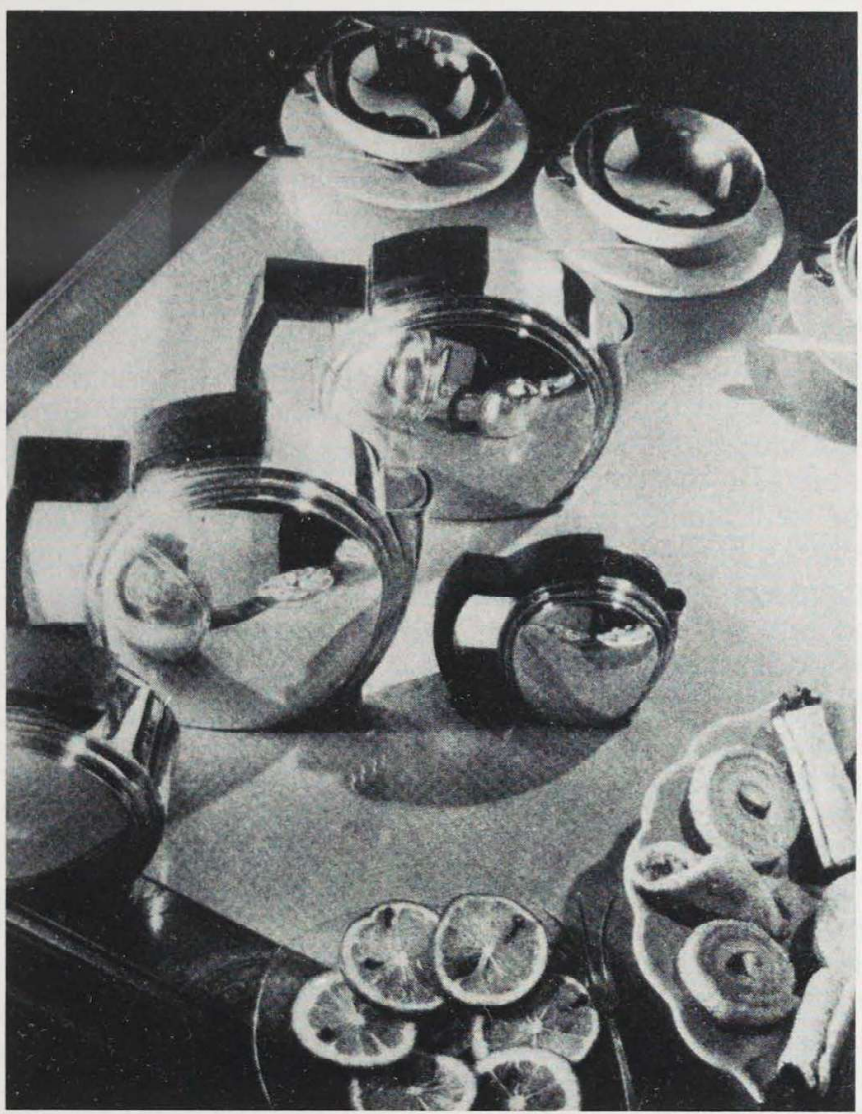

Figure 14 Anton Bruehl.

"Modern Teasets." In Vogue 74 (July 6, 1929), p. 55. Courtesy of the New York Public Library.

A more positive assessment came from Outerbridge and Bruehl, White's protégés. In 1940 Outerbridge described a successful advertising photograph in White's terms: "A sound knowledge of chiaroscuro and a passionate interest in and reaction to the shape of objects devoid of sentimental association is essential to producing the best results (Outerbridge 1940:58). Bruehl also considered his commercial prints works of art. He told an interviewer in 1951 that "a Bruehl client is given one photograph just as he would be given one painting" (Stagg 1951:26). Both Bruehl and Outerbridge also adopted White's flexible approach to photographic means. While straight photographers in the course of the thirties and forties restricted their craft to sharp-focus, black-and-white silver printing, Outerbridge and Bruehl independently pioneered color photography. Bruehl's color-engraving process and Outerbridge's carbro-process ${ }^{50}$ recall the darkroom alchemy of the pictorialists. For both Outerbridge and Bruehl the technical rigor and playful elegance of commercial photography suited their artistic temperaments. Ultimately, however, Bruehl was more able than Outerbridge to channel his art into his commercial work and in the thirties became a major force at Condé Nast. Outerbridge, an eccentric, restless dandy, was simply not a company man, and his most powerful works, the surrealist nudes, were artistically and socially beyond the bounds of 1940 s commercialism. ${ }^{51}$
European modernism provides a third perspective on commercial photography as art. Straight photography, with its insistence on the independence of photography from painting, was a specifically American phenomenon. In Europe a freer interchange between modern art and photography occurred. Commercial photography, instead of being rejected as a fatal compromise, was celebrated as a means of escape from the romantic, individualist tradition. Advertising became an exciting option for socially relevant, technological art. In this context White-inspired design exercises and advertising still lifes provoked interest, especially in Germany (Howe 1977:34). Outerbridge's advertisements appeared frequently in German periodicals, and Steiner, Bruehl, and Outerbridge were all included in the historic Deutsches Werkbund "Film und Foto" exhibition at Stuttgart in 1929. There the works of White's students took their place beside works by the 64 group, the neve sachlich photographs of Renger-Patzch and Moholy-Nagy's "photoplastic studies." 52 The enthusiasm was mutual. In 1936 the Art Center held what was probably the first United States exhibition of European advertising photography (Molderings 1978:93). 


\section{Conclusion}

A reconsideration of White's philosophy of art offers several lessons for students of twentieth-century American photography. For White, the teens and twenties were a period of gradual transition from the symbolist aesthetics of pictorialism to modernismfrom Dow's art principles to Weber's. In this way White, who has been derided as retardataire, presages recent art historical scholarship that emphasizes this same continuous development from symbolism to modernism in early twentieth-century art. ${ }^{53}$ Viewing art photography in this light, and shedding the blinders of the straight photography school, has distinct advantages. It permits a frank acceptance of the pictorialism of the early works of Strand and the $f 64$ photographers, and, at the same time, it encourages a consideration of the symbolist aesthetics in the later works of these artists and of Stieglitz. ${ }^{54}$ It also encourages the exploration of the links between the cubist and abstract experiments in photography and those in other arts. Strand's abstractions, for example, bear comparison with those of Arthur Dove and Georgia O'Keeffe. Steichen's explorations of pure form done in France in 1920 recall the works of his friend Brancusi. Likewise, many of Weston's Mexican works, such as his simplified, monumental "Excusado" and "Palma Cuernavaca" (Weston 19/3: pls. 22, 23) also suggest Brancusi's influence.

White's alliance with the arts and crafts tradition also provides a fresh perspective on the masters of straight photography. The contrast between White's practical aims and the high-art goals of Stieglitz and Strand highlights the romantic, indeed symbolist, orientation of the straight photographers. Recognition of this romantic component weakens the traditionally accepted linkage between Stieglitz and Strand and the documentary photographers of the thirties, forties, and fifties. Io be sure, the documentarians shared with these masters an abhorrence of the issue of pho tographic style and emphasized instead the photographer's direct confrontation with subject matter. But unlike Stieglitz and Strand, the documentary photographers rejected the isolation of the artist from society by submitting their work to the requirements of the FSA and to the national magazines. The documentarians also rejected the isolation of the photograph as a unique work of art by accepting the premise that their works would be reproduced and printed with text. In these ways White rather than Stieglitz blazed the trail.

White's approach also sheds light on the contemporary photography scene. Many contemporary photographers who have turned to photography from painting, video, and conceptual art have disregarded the precepts of straight photography. By freely combining the techniques and goals of other arts with those of both high art and commercial photography, these photographers have in effect resurrected White's approach. Jan Groover's abstract still lifes, for example, hark back to Outerbridge's; Sandy Skoglund's tableaux vivants recall Cecil Beaton's surrealist fashion fantasies; and William Wegman's sumptuous, witty portraits of his dog Man Ray bear comparison with Richard Avedon's portraits and fashion work. Uncovering the overlooked history of modern, commercial photography should help explain and further stimulate these photographers' work. It is ironic that the history of nineteenth-century commercial photography, owing to its "straight" documentary style, has long been granted artistic credibility, while the history of twentieth-century commercial photography, frankly beholden to modern art, has been ignored for its departures from straight aesthetics.

The straight aesthetic gave photography full modernist status, but at a price. Its moral and technical strictures, which created the foundation of avantgarde photography for fifty years, have become constraining. Just as modernism has lost its impetus in other arts, so has straight photography lost its potency for photographers, critics, and photographic historians. The straight view of modern photography posits a standard lineage of masters analogous to the out-dated, formalist version of modern painting which proceeds from Manet to abstract expressionism. It is a view totally ill-equipped to explain the so-called chaos of current art photography. Clarence White's career offers antidotes to these problems. In contrast to the isolation of Stieglitz and Strand, White's network of friends and associates of the 1920s present the picture of a fast-growing, national, indeed interna tional, community of professional art photographers. White's aesthetics, which in their flexibility failed to measure up to the reductive standards of the straight aesthetic, are particularly apropos for postmodernist photography. His 1920 remark-"I do not have any objection to anybody using any method that he pleases providing that the result is convincing"should be heeded by today's critics, who needlessly fret over the "inherent properties of the medium" and isolate art photography from commerce and other arts. White's faith in artistic freedom is a call for the full acceptance - finally - of photography as a fine art. 


\section{Acknowledgments}

My sincerest thanks go to Peter Bunnell, who in a seminar on straight photography initiated my research on Clarence White's later career and the PPA, and to my adviser, J. T. Kirk Varnedoe, whose ideas on photography have conditioned my own and whose encouragement was essential to the completion of this article. I am grateful to Sarah Greenough, whose comments on the manuscript brought into focus many of the fine points of Stieglitz's development. I also wish to thank Paul Shechtman and Laurel Bradley for their careful readings of the manuscript.

\section{Notes}

1 Pultz and Scallen (1981) includes a chapter on the White School The authors present many of the important facts about White, his students, and commercial photography, but their understanding of the style is marred by their applying the aesthetic biases of Stieglitz and Strand. This article hopes to resolve the difficulties of the Pultz/ Scallen approach. Also see Yochelson (1982).

2 Other well-known photographers who studied with White are Margaret Bourke-White, Dorothea Lange, Laura Gilpin, and Doris Ulmann. They have been omitted from this discussion either because they studied with White for a very short time (Bourke-White took a one-semester course at Columbia) or because they were not particularly involved with advertising.

3 Beaumont Newhall's A Short History of Pholography was in its first form a catalog for a MOMA exhibition of 1936; this exhibition was itself tremendously influential in the formulation of the straight photography aesthetic. Both Newhall and Gernsheim are accomplished practitioners of straight photography. It is interesting in this regard that Gernsheim uses his photographs to illustrate the "New Objectivity" section of one of his surveys of photography (Gernsh eim 1962:185-189), associating himself with the German version of the style. A recent, dramatically overt elaboration of the straight approach to early modern photography can be seen in Travis (1979:148). The author's premise is that nineteenth-century, sharpfocus photography adhered to the medium's inherent objectivity; that pictorialism was a short-lived. misguided effort to establish the subjectivity of photography; and that "by the end of the 1920 s American photographers had rediscovered the undisturbed clarity of the photographic image.

4 Strand's talk to White's students in 1923, which has been published numerous times as "The Art Motive in Photography," is the most explicit condemnation of White's adherence to pictorialism ideas. (It was most recently reprinted in Goldberg 1981:276-287.) Strand's view is reflected in the assessment of White's later work in Pultz and Scallen (1981:11, 42).

5 For the best account of the crisis at Buffalo, see Naef 1978:184-201.

6 The interrelation of the three organizations is unrecognized; the role of the Art Center in White's program is the least noticed. Scattered references to the White School or the PPA are the norm. Naomi Rosenblum $(1978: 8,123)$ shows a typically incomplete awareness of White's activities. She mentions White's publication Platinum Print and the PPA but dismisses them thus: "The group involved in this venture were strange bed-fellows with divergent aesthetic ideas; it is understandable that they could not maintain the same enterprise for long." In her discussion of twenties abstract photography, she mentions White's now-forgotten protégés Ira Martin,

Edward R. Dickson, and Henry Hoyt Moore, without establishing their relation to White.
7 It may be through A. W. Dow that White's group exhibited at the Montross Galleries, for his work was shown there. The Ehrich Galleries exhibitions were reviewed in Platinum Print; the 1916 historical show was announced in that journal, but I was not able to find a catalog for it.

8 For the Los Angeles Pictorialists' involvement with the Pan-Pacific Exposition, see Mann 1977:255.

g The 1917 PPA Yearbook outlines the goals and structure of the organization.

10 While Stieglitz was never concerned with the classroom teaching of photography, he had a strong commitment to educating photographers and the public about art and photography. His numerous articles of the 1880s and 1890s as well as Camera Work and "291" were his educational tools. In a 1902 interview with Theodore Dreiser, Stieglitz spoke of establishing a museum/school of photography, although he never pursued this idea. I thank Sarah Greenough for bringing this issue to my attention.

11 It is interesting that both Dow's and White's students were primarily female. In Dow's case this is easily explained; his students were training to be teachers, a woman's profession (Moffatt 1977:83, 94 101). White's case is a little more difficult to understand. Laura Gilpin, who has said that Stieglitz and Steichen were "not the least bit interested in women photographers," offers the beginning of an explanation (Hill and Cooper 1979:285).

12 Coburn's relation to Dow has been well examined (Moffatt 1977:98-99; Pultz and Scallen, 1981:15). For Weber's reliance on Dow, see Moffatt 1977:82-83. White's dependence on Dow is mentioned in Pultz and Scallen 1981:42.

13 Moffatt (1977:63) suggests Charles Blanc as a source for Dow's design principles. Blanc's traditional academic principles have been connected with symbolist aesthetics such as Puvis de Chavannes's. Dow's theories reenforce the connection. The question of academicism and White's teaching deserves comment. Strand condemned White's design principles as academic, by which he meant "perfectly dead things" (Goldberg 1981:283). This view is accepted by Pultz and Scallen (1981:43). The history of avant-garde art in the nineteenth and twentieth centuries belies this view; the greatest innovators began with rigorous formal training: Manet with Couture, Matisse with Moreau, etc. White hoped to place photographers within this tradition.

14 White's papers belong to Princeton University. Among them are various papers from the Clarence $\mathrm{H}$. White School of Photography. Three brochures are included; none is dated, though all postdate White's death. The description of the project method and all assignments are culled from these brochures.

15 In April-May 1919 the American Institute of Graphic Arts held an exhibition of commercial art. All the graphic arts and all commercial uses were represented. White chose the photography section and wrote an introduction. Also associated with the exhibition was Heyworth Campbell.

16 The pamphlet "Art Center 1926" serves as an introduction to the Art Center, explaining its membership, activities, and goals.

17 Bement wrote an article, "Design," which appeared in the 1925 PPA annual. His views on modern art were conservative and close to Dow's, that is, tentative about modern art after 1900. Bement was Georgia O'Keeffe's teachier; he recommended Dow to her in 1912.

18 The most distinguished one-man exhibitions, culled from the Art Center Bulletin, are Käsebier, November 1922; Edward Weston, winter 1922; Arnold Genthe, March 1923; Laura Gilpin, January 1924; Outerbridge, March 1924; "Our California Friends," October 1924; Sheeler, February 1926: White Memorial, April 1926: Doris Ulmann, November 1926; Bruehl, December 1926; Bruguière. March-April 1927; William Mortensen, June 1927. These exhibitors practiced all photographic styles; they share the practice of commercial photography. 
19 The second (1925) and third (1929) salons were documented in the fourth and fifth annuals. A fourth salon took place sometime between 1929 and 1938, when the fifth salon was held at the American Museum of Natural History. The International Salon of Photography continued with near regularity until 1956. The 1938 saIon had three sections: pictorial (319 prints), modern (71 prints), and illustration ( 45 prints). The modern section was juried by Beaumont Newhall, Hyatt Mayor, and Elizabeth McCausland. Newhall wrote the introduction, which states that "the term Modern Photography is here used to define the experimental exploitation of pure photography." The 1936 MOMA show is clearly felt in the essay and selection. The pictorial section of this exhibition is unoriginal, retardataire, and amateur in the worst sense. It is undoubtedly from displays such as this that pictorialism's reputation sank to the depths. In the 1940 (seventh) salon there was no modern section. The PPA by that time no longer tried to embrace all "artistic" photography.

20 An important exception to Stieglitz's increasingly private life in the teens was his judging the photography exhibitions held at the Wanamaker department store in Philadelphia from 1912 to 1920. In total opposition to the "291" concept, these exhibitions were huge and included the awarding of prizes. Sarah Greenough brought this puzzling situation to my attention. By the 1920 s Stieglitz did become increasingly unreceptive to the work of young photographers. When Ralph Steiner approached him for advice he was told, "I do not help individuals" (Steiner 1978:6). Both Imogen Cunningham and Laura Gilpin said they were afraid to go see Stieglitz, and when Cunningham finally showed him her work in 1934, he was "not at all" interested (Hill and Cooper 1981: 284, 296, 306). Outerbridge took a portfolio to Stieglitz, yet there is no indication that their first meeting led to a second (Howe 1977:10, 1980:11). Walker Evans showed his work to Stieglitz and received no encouragement (Naef 1978:234; Steiner 1978:7)

21 The 1922 PPA annual listed Stieglitz's 1921 show as one of the year's important events, noting that "a master has come back" (Moore 1922:12). John Tennant's reaction was ecstatic (Newhall 1982:171).

22 See Newman (1981:30-35) for a detailed description of Stieglitz's control over Dove's relationship with Phillips.

23 For comments on White's gentle, encouraging manner as a teacher, see White 1977:23-24.

24 In Naef (1978:196), Stieglitz's choice of the term "pictorial" is criticized: "It is baffling that Stieglitz would have even used the term 'pictorial' to describe what he stood for at this late date .... associat(ing) him and his colleagues with what would be the most despised art movement of the 20th century, pictorialism in its late phases." Organized, amateur pictorial photography as it persisted in the 1930s and later is indefensible (see note 19, above), but the exhaustion of pictorialism should not be retroactively applied to 1910.

25 The debate on straight photography began in England with P. H. Emerson's attack on the aesthetics of H. P. Robinson in the mid-1880s. Camera Work illustrates the transitional stage of the debate, before the emergence of straight photography as a modernist ideal in the 1920s. This middle stage is best illustrated by comparing G. B. Shaw's "The Unmechanicalness of Photography" with Robert Demachy's "On the Straight Print" (Green 1973:62-66ff, 118-122)

26 Efforts to define the stylistic preferences of the straight aesthetic in the 1920s is admittedly dangerous. In the 1930s the f64 group definitely established the style: sharpest focus, highest contrast, and use of silver gelatin paper. Stieglitz's and Strand's works of these years show higher contrast and sharper focus than pre-World I pictorialist works, but they did prefer the softness and subtlety of platinum paper, using silver paper at first only because platinum paper was no longer commercially manufactured after the war. In his 1923 talk at the Art Center, Stieglitz railed against Kodak for discontinuing platinum paper (Stieglitz 1976)
27 Again, Strand's "The Art Motive in Photography" is his clearest condemnation of pictorialism for its "unphotographic" principles and results (Goldberg 1981:276-287).

28 The reviewer was Edward R. Dickson, an amateur and loyal White follower who edited Platinum Print and did the routine work generated by White's efforts from 1913 until 1922; Dickson died that yoar

28 Naomi Rosenblum (1978) points out Strand's contacts with the Arensberg circle and Stieglitz's "291" circle and makes some rather perfunctory comparisons of Strand's photographs with paintings. Because of Rosenblum's reliance on Strand's own philosophy she does not attempt a thorough analysis of the influence of painting on Strand's works. William Homer (19/7:249) makes the general connection between Strand's abstractions and Hartley and Dove Strand himself reportedly stated that his experiments with abstraction were exercises for him which he abandoned for his confrontation with life (see Goldberg 1981:290). Stieglitz's connections with modern artists and ideas have been extensively documented. but systematic comparison of his works with paintings has yet to be published. See Naef 1978:214, 224 for some useful remarks.

30 John Szarkowski (1973:96) clearly explains the moral component of straight photography in Strand's terms.

31 A good summary of Weber's assimilation of French influence can be found in Homer (1977:126-138). Weber's art rhetoric, with its stress on the connection of abstraction and musical correspondences, for example, seems to reflect Kandinsky's On the Spiritual in Art.

32 Space-filling is probably inherited from Dow and his orientalist collaborator, Ernest Fenellosa (see Moffatt 1977:49).

$33 \mathrm{Karl}$ Struss held on to the concept of space-filling throughout his career. John Harvith (1976:4) associates space-filling with straight photography rather than with modern art, referring to composing in the ground glass before exposing a negative.

34 Pultz and Scallen (1981:42) discuss the Weber exercises. Calling therm "decorative abstractions," the authors imply that the works are superficial in their approach to cubism. Weber thoroughly understood cubism as well as other modernist ideas; his shortcoming was his lack of photographic knowledge.

35 The most significant and earliest experiments in abstract photography were by Strand and Coburn in the teens. Their philosophies were incompatible; Strand saw his work as a radical departure from pictorialism and Coburn saw his as an outgrowth of pictorialism. It should be noted that Strand's abstract works could involve as much manipulation as Coburn's. Coburn's Vortographs were made using prisms to splinter forms; Strand's Porch Shadows is turned ninety degrees in order to render the subject unrecognizable.

36 The same combination of soft-focus, platinum printing, and spacefilling is found in the work of Karl Struss, whose aesthetic preferences were closest of all White's colleagues to his own. Although Struss has received some attention (e.g., Harvith 1976; Pultz and Scallen 1981:12), his contribution to modern photography has been underestimated because of his use of the soft-focus lens. He experimented with high vantage points and odd cropping to capture the drama of New York street life as early as 1910, before Coburn or Strand.

37 Also see Szarkowski (1973:50); while the author remains sensitive to White's works, his attitude toward White's aesthetics is condescending.

38 Frank Crowninshield (editor of Vanity Fair), in "Vogue-Pioneer in Modern Photography," June 15,1941, pp. 27-33ff.), wrote that the two Condé Nast magazines discovered and developed more photographers of the first order than any other periodicals of record 
39 "The Release of the Hamadryad: a Recent Photographic Study; Made in Southern California by Karl Struss" (December 1920, p. 62). "Hamadryads and Sisters of Narcissus; Camera Studies Made Against the California Hills by Margarethe Mather and E. Weston" (January 1921, p. 60). Sheeler, "Cubistic Architecture in New York" (January 1921, p. 72) . Experiments in Abstract Form, Made Without a Camera Lens by Man Ray, the American Painter" (November 1922, p. 50). Francis Bruguière, "A Modernist Setting for the New Production of Macbeth" (April 1921, p. 46). "Experiments with Modernistic Photography; Ira Martin Attempts to Solve with the Camera Some of the Problems which Confront the Cubist Painter" (July 1921, p. 60). "Photography Comes into the Kitchen; A Group of Photographs by Margaret Watkins Showing Modernist, or Cubist, Patterns in Composition" (October 1921, p. 60). Note that the pictorialist Mather/Weston photograph was in the same issue with Sheeler's "cubistic architecture." Slightly later, Outerbridge was featured with "The Kitchen Table: A Study in Ellipses, Suggesting How the Modern Conception of Abstract Design May be Applied to Still Life" (July 1922, p. 52). This series was from time to time continued. In 1924 Stieglitz's "The Steerage" was reproduced (August, p. 54), as was one of his portraits of Georgia O'Keeffe (July, p. 49). These may have been inspired by his "reemergence" with the Anderson Galleries shows. In January 1931 (p. 56) Outerbridge was again featured with a photograph of a piano titled "Music," which he had made in 1924. The short article accompanying the photograph mentioned that the Museum of Modern Art had recently purchased ten Outerbridge photographs; in 1929 the Metropolitan had accepted his gift of ten photographs.

40 Art Center Bulletin 6(5) (February 1928); a report on a Campbell talk at the Art Center mentions his association with White "in the days of the Photo-Secession, Little Galleries, and 291." In this talk Campbell reviewed the "old masters": White, Stieglitz, Steichen, Käsebier, and Coburn.

141 The interpretive dance of Isadora Duncan, Loie Fuller, Ruth St. Denis, and others, which stressed personal expression and the glorification of feminine beauty, was a favorite pictorialist subject. Arnold Genthe's The Book of the Dance (1916). Steichen's Duncan photographs of 1921, and a special dance issue of Platinum Print 2(2) (1915) are noteworthy examples of this vogue.

42 Sheeler like Steichen was granted more artistic credibility hecause he was a painter as well as a photographer. His architectural paintings and his photographs were published in Vanity Fair. In April 1921 . p. 47, a painting based on a photograph appeared, subtitled "Above the Turmoil of New York"; its caption explains that Sheeler considered architecture "purely as an arrangement of planes and angles." In the late 1920s skyscraper photographs appeared in Vanity Fair again-Ralph Steiner's in April 1928, p. 58, and Ira Martin's in November 1929, p. 86

43 The "Ide Shirt Collar," perhaps Outerbridge's most famous photograph, is an excellent example of an advertisement doubling as art Marcel Duchamp realized this in the 1920s. Outerbridge discovered his "Collar," an artful ready-made with a "chessboard" background, on Duchamp's studio wall in Paris in 1925 (Howe 1980:11). This photograph is equivocally discussed by Pultz and Scallen 1981:43.

44 Steichen's talk was reported in the Art Center Bulletin 1(9) (April 1923), pp. 164-165. Steichen also spoke at White's School on February 15, 1923, according to miscellaneous School notes at Princeton.

45 Cf. "On Ideas," Pictorial Photography in America 3(1922), pp. 13-14, with Art Center Bulletin 3(1) (Sept. 1924), p. 14, a report on Campbell's talk to the PPA. Campbell's conversion came too late; he was replaced by Dr. M. F. Agha as art director not long after Steichen joined the staff (Steichen 1963). White's group, however, carried on with Agha. He and Frank Crowninshield wrote essays for the 1029 PPA annual.

16 The French deco designers Louis Suë and André Mare claimed, "No matter what beautiful antique should be in one's home amidst our furniture, it should be received as an ancestor and not as an intruder" (Hunter 1972)
47 By 1927 all of its exhibitions were touched by le style moderne, and in 1930 it redesigned its Bulletin.

48 "Advertising and Photography," Pictorial Photography in America 4(1926), no pagination; an excerpt can be found in Pultz and Scallen 1981:41-42.

49 The text of Stieglitz's talk at the Art Center, which was published by the Center for Creative Photography in 1976, is based on Rebecca Strand's notes and was "corrected and developed" either by their owner Dorothy Norman or by the editors of the journal. "A New York Art Center" was The Art Center. The Art Center Bulletin announced the talk in $1922(1: 5)$ and reported on it in 1:6 (January 1923), pp. 95-96. These dates conflict with the generally accepted date for Stieglitz's rapprochement with White, dated by a letter from White to Stieglitz of October 1923 in the Stieglitz Collection at Yale (see White 1977:28 and Naef 1978:224). Stieglitz's talk at the Art Center occurred on December 4, 1922; it was thus announced in the Art Center Bulletin, and Stieglitz mentioned the day December 4 in the published version of the talk. Stieglitz also spoke at White's School before this December talk; in the published account of his Art Center talk he recalls speaking at the White School: "He [the host] told me he had heard me at the Clarence White School. Now anyone who had heard me at the White School must be a hero" ( $p$. 2). For Strand's talk, see note 4. Rosenblum gives further evidence of Strand's desire to disassociate himself from White and pictorialism; he rejected White's invitation to submit to a photographic annual based on the English Photograms of the Year, that is, the PPA annual.

50 Outerbridge's process is briefly described in Howe 1980:16: Bruehl's in Deal 1976. Outerbridge's book Photographing in Color (1940) and Bruehl's book Color Sells (1935) of course go into greater detail.

51 Howe (1980:18-21) gives an interesting account of Outerbridge's later years and work, emphasizing the unacceptability of his fetish istic nudes. Also noteworthy is the difference between Howe's two publications on Outerbridge; the 1977 exhibition catalog deemphasizes them, and the 1980 coffee table book features them. This change is no doubt in part due to the increased interest in color photography in the last few years.

52 The American section of the "FiFo" exhibition was selected by Steichen and Weston. American (excluding emigrés) were Rerenice Abbott, Bruehl, Cunningham, Outerbridge, Sheeler, Steiner, Steichen, and Brett and Edward Weston. Stieglitz and Strand were not included. Beaumont Newhall, in his illustrations for Ferdinand Léger's 1926 essay, "A New Realism-The Object: Its Plastic and Cinematic Value," juxtaposes a Ralph Steiner close-up of typewriter keys with close-ups by Brett Weston and August Sander (Newhall 1980:233). The same photograph is published in Steiner 1978:5 as an example of the design exercises he did at White's School. This same exercise is discussed by Pultz and Scallen 1981:44. While Newhall places Steiner's close-up in the context of other close-ups which derive from different modernist theories, Pultz and Scallen try in vain to distinguish Steiner's work from Outerbridge's on the basis of White's versus Strand's aesthetics: 'Unlike Outerbridge's, Steiner's concern is for the object itself, using only point of view and cropping to achieve the final effect, without dependence on arrangement." This is especially futile, considering that Steiner's photography predates his conversion to Strand's views by several years.

53 The 1982 exhibitions on Kandinsky in Munich at the Guggenheim and on Richard Neutra at MOMA both demonstrate a gradual transition from art nouveau and symbolism to early modernism.

54 Weston's nature close-ups can be considered in relation to art nouveau ideas about natural forms; a comparison with Karl Blossfeldt's Urformen would be illuminating. Stieglitz's use of the term "equivalents" for his late landscapes and cloud studies places them within the orbit of symbolism. These works, as projections of Stieglitz's feeling toward his own isolation and love of nature, also conform to "the northern romantic tradition" (Rosenblum 1975) 


\section{References}

- Art Center

1921 First Exhibit (November 1-30). New York: The Art Center Inc.

1926 The Art Center and Industry. New York: The Art Center, Inc

- Bunnell, Peter, ed.

1980 A Photographic Vision: Pictorial Photography, 1889-1923.

- Deal, Joe Salt Lake City: Peregrine Smith, Inc.

1976 Anton Bruehl. Image 19(2): 1-9.

- Gernsheim, Helmut

1962 Creative Photography, Aesthetic Trends 1939-1960. New York: Crown Publishers.

- Goldberg, Vicki, ed.

1981 Photography in Print: Writings from 1816 to the Present. New York: Simon and Schuster.

- Green, Jonathan, ed

1973 Camera Work: A Critical Anthology. Millerton: Aperture.

- Harvith, John

1976 Karl Struss: Man with a Camera. Bloomfield Hills, Mich. Cranbrook Academy of Art/Museum.

- Hill, Paul, and Thomas Cooper, eds.

1979 Dialogue with Photography. New York: Farrar Straus Giroux

- Homer, William Innes

1977 Alfred Stieglitz and the American Avant-Garde. Boston: New York Graphic Society.

- Howe, Graham

1977 Paul Outerbridge, Jr. Los Angeles: Los Angeles Center for Photographic Studies.

1980 Paul Outerbridge. Jr.: Photographs. New York: Rizzoli International.

- Hunter, Penelope

1972 Art Deco, The Last Hurrah. Metropolitan Museum of Art Bulletin 30(6) (June/July)

- King, Edith Morgan

1929 Modernism? Vogue (May 11, 1929):104ff.

- Mann, Margery

1977 California Pictorialism. San Francisco: Museum of Modern Art.

- Moffatt, Frederick C.

1977 Arthur Wesley Dow (1857 1922). Washington, D.C.: National Collection of Fine Arts

- Molderings, Herbert

1978 Urbanism and Technological Utopianism: Thoughts on the Photography of Neue Sachlichkeit and the Bauhaus. In Germany: The New Photography 1917-1923. David Mellor. ed. London: Arts Council of Great Britain. Pp. 87-94

- Moore, Henry Hoyt

1921 The Year's Progress. Pictorial Photography in America 2

1922 The Year's Progress. Pictorial Photography in America 3.

- Naef, Weston

1978 The Collection of Alfred Stieglitz: Fifty Pioneers of Modern Photography. New York: Metropolitan Museum of Art.

- Newhall, Beaumont

1980 Photography: Essays and Images. New York: Museum of Modern Art.

1982 The History of Photography: 1839 to the Present. 5th ed. New York: Museum of Modern Art.

- Newman, Sasha

1981 Arthur Dove and Duncan Phillips: Artist and Patron. New York: Braziller.

- Outerbridge, Paul, Jr.

1940 Photographing in Color. New York: Random House.

- Pultz, John, and Catherine B. Scallen

1981 Cubism and American Photography, 1910-1930. Williamstown, Mass.: Sterling and Francine Clark Art Institute.
- Reed, Helen Appleton

1929 Modernism in a Museum. Vogue (April 27): 75ff. Review of annual exhibition of American industrial arts at the Metropolitan Museum of Art, with photos by Anton Bruehl.

- Richards, Charles R

1926 Modern Decorative Arts from Paris at the Metropolitan Museum of Art. Magazine of Art 17(4) (April):170-174. Review of exhibition which traveled from New York to Boston, Cleveland, Detroit, Minneapolis, St. Louis, Pittsburgh, and Philadelphia.

- Rosenblum, Naomi

1978 Paul Strand: The Early Years, 1910-1932. Ph.D. dissertation, CUNY.

- Rosenblum, Robert

1975 Modern Painting and the Northern Romantic Tradition: Friedrich to Rothko. New York: Harper and Row.

- Stagg, Mildred

1951 Anton Bruehl. Modern Photography 15(9) (September):26-33ff.

- Steichen, Edward

1963 A Life in Photography. Garden City: Doubleday. Opposite plate 95.

- Steiner, Ralph

1978 A Point of View. Middlotown, Conn.: Weslcyan University Press.

- Stieglitz, Alfred

1976 A Stieglitz Talk at a New York Art Center. The Center for Creative Photography 1 (March).

- Szarkowski, John

1973 Looking at Photographs. New York: Museum of Modern Art

- Travis, David

1979 Photography Rediscovered: American Photographs

- Weber, Max

1913 The Filling of Space. Platinum Print 1(2):6

- Weston, Edward

1973 The Daybooks of Edward Weston. Vol. 1: Mexico. Nancy Newhall, ed. Millerton: Aperture

- White, Maynard P., Jr.

1977 Clarence H. White: Artist in Life and Photography. In Symbolism of Light: The Photographs of Clarence $\mathrm{H}$. White Wilmington: Delaware Art Museum.

- Yochelson, Bonnie

1982 Review of Pultz's and Scallen's Cubism and American Photography. Artforum 21(4) (December):82-83. 